\title{
Molecular Wires using (Oligo)pyrroles as Connecting Units - An Electron Transfer Study
}

Ulrike Pfaff,,$^{\dagger}$ Alexander Hildebrandt,$^{\dagger}$ Dieter Schaarschmidt ${ }^{\dagger}$ Tobias Rüffer,${ }^{\dagger}$ Paul J. Low ${ }^{\ddagger}$ and Heinrich Lang*,†

${ }^{\dagger}$ Institute of Chemistry, Inorganic Chemistry, Technische Universität Chemnitz, Faculty of Natural Sciences, D-09107 Chemnitz, Germany

${ }^{\star}$ School of Chemistry and Biochemistry, University of Western Australia, Crawley, Perth, WA, Australia

\begin{abstract}
A series of (oligo)pyrroles featuring redox-active terminal ferrocenyl groups $\left(\mathrm{Fc}_{2}-\left({ }^{c} \mathrm{C}_{4} \mathrm{H}_{2} \mathrm{NPh}\right)_{\mathrm{n}}(\mathbf{4}, \mathrm{n}=\right.$ $1 ; \mathbf{9}, \mathrm{n}=2 ; \mathbf{1 6}, \mathrm{n}=3 ; \mathbf{2 0}, \mathrm{n}=4)$ ) has been prepared using a Negishi $C, C$ cross-coupling reaction protocol. The bi-, ter- and quarterpyrrole wire moieties have been built up by $C, C$ cross-coupling reactions of trimethyl silyl protected pyrrole units in the presence of $\left[\mathrm{Pd}\left(\mathrm{CH}_{2} \mathrm{C}\left(\mathrm{CH}_{3}\right)_{2} \mathrm{P}\left({ }^{t} \mathrm{C}_{4} \mathrm{H}_{9}\right)_{2}\right)(\mu-\mathrm{Cl})\right]_{2}$ as precatalyst. The structural properties of the title compounds were investigated by spectroscopic means and single-crystal X-ray diffraction studies $(\mathbf{9}, \mathbf{1 6}$ and 20). The influence of the increasing number of $N$-phenyl pyrrole units on the electronic interaction between the iron centres was studied
\end{abstract}


using electrochemistry (cyclic $(\mathrm{CV})$ and square wave voltammetry (SWV)) as well as spectroelectrochemistry (in situ UV-Vis/NIR spectroscopy). With exception of the diferrocenyl quarterpyrrol 20, the application of $\left[\mathrm{N}^{n} \mathrm{Bu}_{4}\right]\left[\mathrm{B}\left(\mathrm{C}_{6} \mathrm{~F}_{5}\right)_{4}\right]$ as electrolyte allows the discrete oxidation of the ferrocenyl termini $\left(\Delta E^{\circ \prime}=450 \mathrm{mV}(\mathbf{4}), \Delta E^{\circ \prime}=320 \mathrm{mV}(\mathbf{9}), \Delta E^{\circ \prime}=165 \mathrm{mV}(\mathbf{1 6})\right)$ in cyclic and square wave voltammograms. However, the iron centres of $\mathbf{2 0}$ were oxidized simultaneously, generating dicationic $\mathbf{2 0}^{2+}$. Additionally, one (9) or two (16 and 20) pyrrole-related well-defined reversible one-electron redox processes were observed. The cyclic voltammetry data reveal that the splitting of the ferrocene-based redox couples, $\Delta E^{\circ \prime}$, decreases with increasing oligo-pyrrole chain length and hence, the larger metalmetal distance. The trends in $\Delta E^{\circ \prime}$ with oligo-pyrrole structure also map to the electronic coupling between the ferrocene moieties as estimated by spectroelectrochemical UV-Vis/NIR measurements. Despite no direct metal-metal interaction in diferrocenyl quarterpyrrole $\mathbf{2 0}$, a large absorption in the NIR region is observed arising from photo-induced charge transfer from the oligopyrrole backbone to the redox-active ferrocenyl termini. These charge transfer absorptions have also been found in the dicationic oxidation state of the mono-(4), bi- (9) and terpyrroles (16). Within this series of diferrocenyl(oligo)pyrroles this CT band is shifted bathochromically with increasing chain length of the backbone motif.

\section{INTRODUCTION}

During the last four decades significant interest has been focused on $\pi$-conjugated organic materials, which in addition to offering useful electronic and optical properties, for example, conductivity and electrochromism, are also finding application in the growing field of molecular electronics. ${ }^{1-6}$

A convenient method through which to assess the effective delocalization of the $\pi$-electron density in these extended organic materials is to assess the mixed-valence characteristics of model complexes in which the target organic moiety serves as a bridging unit between two (or more) redox-active functionalities such as metallocenes ${ }^{7,8}$ and iron $^{7,9}$ or ruthenium ${ }^{9,10}$ half-sandwich compounds. Due to the 
excellent thermal stability and electrochemical reversibility of the ferrocene $[\mathrm{Fe}(\mathrm{II}) / \mathrm{Fe}(\mathrm{III})]$ redox couple, ferrocene is well-suited to such investigations. ${ }^{11,12}$ Many such ferrocene-based model systems with two redox-active termini have been described featuring a variety of $\pi$-conjugated organic bridges, i.e. diferrocenyl-polyenes, ${ }^{13}$-arenes,${ }^{14-17}$-cumulenes ${ }^{18}$ and -oligo(phenylenevinylenes), ${ }^{19}$ and the redoxproperties and electronic structures correlated with the wire-like behavior of the bridge. Of particular relevance to the present study are Sato's ter- to sexi-thiophene bridged bis-ferrocene complexes. ${ }^{20,21}$ These molecules were accessible by the Negishi cross-coupling of $\mathrm{FcZnCl}$ with the appropriate iodocompounds. However, despite the intuitively appealing chemical structure, no direct interaction of the ferrocenyl units through the oligo(thiophene) chain was observed.

In a recent study we were able to show that the electron-rich pyrrole connecting unit is superior to the thiophene molecule in terms of promoting electronic interactions between ferrocenyl/ferrocenium termini. $^{22}$ In that earlier work, a series of 2,5-diferrocenyl substituted furans, thiophenes and pyrroles were prepared and studied by electrochemical and spectroelectrochemical methods. The ferrocenyl moieties of these compounds showed two well-separated reversible one-electron redox processes. The separation of the redox potentials of 2,5-diferrocenyl- $N$-phenyl pyrrole $\left(\Delta E^{\circ \prime}=450 \mathrm{mV}\right.$, supporting electrolyte: $\left.\left[\mathrm{N}^{n} \mathrm{Bu}_{4}\right]\left[\mathrm{B}\left(\mathrm{C}_{6} \mathrm{~F}_{5}\right)_{4}\right]\right)$ was found to be much larger than those of 2,5-diferrocenyl thiophene $\left(\Delta E^{\circ \prime}=260 \mathrm{mV}\right)$ under the same measurement conditions. ${ }^{16,22,23}$ Given the similar solvation, ion-pairing, inner and outer-sphere reorganisation energies, the $\Delta E^{\circ \prime}$ likely tracks reasonable well with the magniture of 'electronic coupling' between the redox centers. ${ }^{24}$ This prompted us to investigate model systems for molecular wires containing oligo(pyrrole) units, which might offer the possibility to observe electron transfer between the ferrocene-based redox centers through relatively long oligo-heterocyclic backbones.

We herein describe the synthesis of a series of diferrocenes bearing (oligo)pyrrole connecting units. (Spectro)electrochemical methods have been used to examine the effect of an increasing distance between the ferrocenyl moieties on the intermetallic communication of these complexes. 


\section{RESULTS AND DISCUSSION}

\section{Synthesis and characterization}

Diferrocenyl (oligo)pyrroles $\mathrm{Fc}_{2}-\left({ }^{c} \mathrm{C}_{4} \mathrm{H}_{2} \mathrm{NPh}\right)_{\mathrm{n}}(\mathbf{4}, \mathrm{n}=1 ; \mathbf{9}, \mathrm{n}=2 ; \mathbf{1 6}, \mathrm{n}=3 ; \mathbf{2 0}, \mathrm{n}=4$ ) have been prepared in two steps (Schemes 1 and 2), involving assembly of the (oligo)pyrrole backbone $(\mathbf{8}, 14$ and 18) followed by the attachment of the ferrocenyl termini. Initially, $N$-phenylpyrrole was treated with one or two equivalents of $\mathrm{N}$-bromo-succinimide as described by Gilow et al.$^{25}$ The electrophilic bromination selectively forms mono- or di-halogenated pyrroles $(\mathbf{2}, \mathbf{5})$. Bipyrrole 7 was synthesized by a Negishi $C, C$ cross-coupling reaction of 2-bromo- $N$-phenyl-pyrrole (5) with the zinc species $2-\mathrm{ZnCl}^{c} \mathrm{C}_{4} \mathrm{H}_{3} \mathrm{NPh}(\mathbf{6})$, using $\left[\mathrm{Pd}\left(\mathrm{CH}_{2} \mathrm{C}\left(\mathrm{CH}_{3}\right)_{2} \mathrm{P}\left({ }^{t} \mathrm{C}_{4} \mathrm{H}_{9}\right)_{2}\right)(\mu-\mathrm{Cl})\right]_{2}$ as precatalyst (Scheme 1). ${ }^{17,26}$ The work-up and further reactions were carried out in neutral or alkaline media to prevent protonation, which in turn causes decomposition or polymerization of the molecules. In order to synthesize ter- (14) and quarterpyrroles (18), $\mathrm{Me}_{3} \mathrm{Si}$-protected bromo oligo(pyrroles) 10, 11 and 12 were used in the cross-coupling reactions (Scheme 1). Deprotection to give 14 and 18 was carried out with an excess of tetra- ${ }^{n}$ butylammonium fluoride under moderate conditions (Experimental Section).

Scheme 1. Synthesis of oligopyrroles $2,8,14$ and 18 ((i): $60{ }^{\circ} \mathrm{C}, 12 \mathrm{~h}$, tetrahydrofuran, $0.25 \mathrm{~mol} \%$ $\left[\mathrm{Pd}\left(\mathrm{CH}_{2} \mathrm{C}\left(\mathrm{CH}_{3}\right)_{2} \mathrm{P}\left({ }^{t} \mathrm{C}_{4} \mathrm{H}_{9}\right)_{2}\right)(\mu-\mathrm{Cl})\right]_{2},(\mathrm{NBS}=N$-bromosuccinimide $\left.)\right)$.
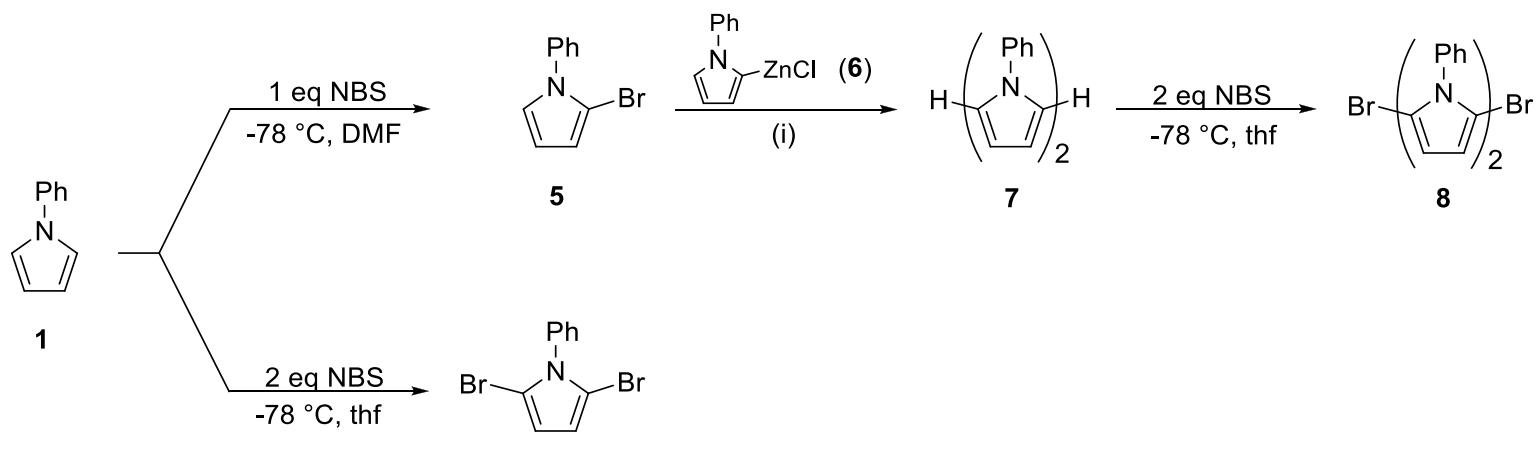

2

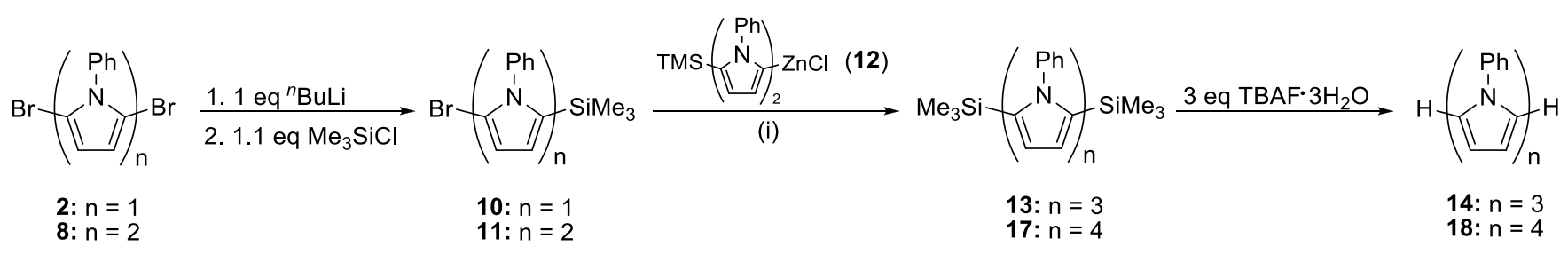


The introduction of the ferrocenyl substituents was realized by the convenient synthetic methodology shown in Scheme 2. Compound 1 and the fluorescent (oligo)pyrroles 7, 14 and 18 were treated with two equivalents of $\mathrm{N}$-bromosuccinimide resulting in the formation of dibrominated $\mathbf{2}, \mathbf{8}, \mathbf{1 5}$ and $\mathbf{1 9}^{25}$ Ferrocene was monolithiated according to the procedures reported by Müller-Westerhoff ${ }^{27}$ followed by treatment with $\left[\mathrm{ZnCl}_{2} \cdot 2\right.$ thf] to give $\mathrm{FcZnCl}, 3$. Subsequent reaction of $\mathbf{3}$ with $1 / 3^{\text {rd }}$ equivalents of the dibromo compounds $\mathbf{2}, \mathbf{8}, \mathbf{1 5}$ and 19 under Negishi $C, C$ cross-coupling conditions and appropriate workup gave the (oligo)pyrroles 4, 9, 16 and 20 as orange solids in moderate to good yields (Experimental Section).

Scheme 2. Synthesis of diferrocenyl (oligo)pyrroles 4, 9, 16 and 20 ((i): $60{ }^{\circ} \mathrm{C}, 12 \mathrm{~h}$, tetrahydrofuran, $0.25 \mathrm{~mol} \%\left[\mathrm{Pd}\left(\mathrm{CH}_{2} \mathrm{C}\left(\mathrm{CH}_{3}\right)_{2} \mathrm{P}\left({ }^{t} \mathrm{C}_{4} \mathrm{H}_{9}\right)_{2}\right)(\mu-\mathrm{Cl})\right]_{2},(\mathrm{NBS}=\mathrm{N}$-bromosuccinimide $\left.)\right)$.

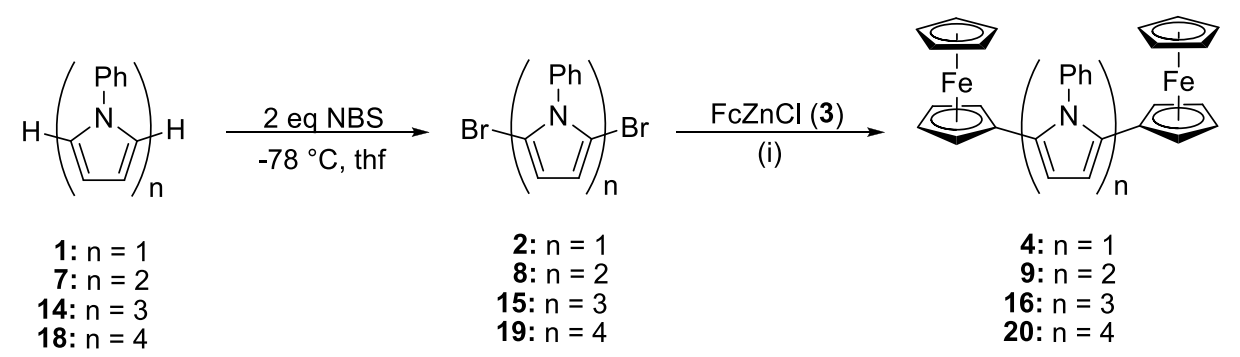

The diferrocenyl (oligo)pyrroles 4, 9, 16 and 20 are stable to air and moisture both in the solid state and in solution. They are poorly soluble in non-polar solvents such as $n$-hexane, diethyl ether and toluene but show good solubility in dichloromethane and tetrahydrofuran. Each of the compounds has been identified by NMR $\left({ }^{1} \mathrm{H},{ }^{13} \mathrm{C}\left\{{ }^{1} \mathrm{H}\right\}\right)$ and IR spectroscopy as well as elemental analysis. In addition, high resolution ESI-TOF mass spectrometric measurements and single crystal X-ray diffraction studies (9, 16 and 20) have been carried out. The electrochemical behavior of 4, 9, 16 and 20 was determined by cyclic voltammetry $(=\mathrm{CV})$, square wave voltammetry $(=\mathrm{SWV})$ and the redox products studied further by in situ UV-Vis/NIR spectroelectrochemical methods. 
The IR spectra are less meaningful for the determination of the (oligo)pyrrolic chain length since they only show typical absorptions for the pyrrole moieties, the phenyl ring and the ferrocenyl units. The $\mathrm{Me}_{3} \mathrm{Si}$-protected oligopyrroles $10,11,13$ and 17 show typical symmetric $\left(v_{\mathrm{s}-\mathrm{CH} 3}\right)$ and asymmetric $\left(v_{\text {as- } \mathrm{CH}}\right)$ stretching vibrations below $3000 \mathrm{~cm}^{-1}$ (Experimental Section). In contrast to the IR spectra, ${ }^{1} \mathrm{H}$ NMR spectra are more informative, with characteristic patterns of phenyl-pyrrole resonances clearly indicating the different number of pyrrole units. The terpyrroles 13, 14, 15 and 16 show a singlet for the protons of the middle pyrrole core between 5.72 to $6.36 \mathrm{ppm}$ (Experimental Section). However, the bipyrroles 8 - 10 and quarterpyrroles 17, 19 and $\mathbf{2 0}$ give two and four doublets corresponding to the $\mathrm{CH}$ protons of the pyrrole ring. Furthermore, these resonances are slightly shifted to higher field with increasing chain length. As expected the ferrocenyl units with their $\mathrm{C}_{5} \mathrm{H}_{5}$ and $\mathrm{C}_{5} \mathrm{H}_{4}$ cyclopentadienyl rings give rise to one singlet $\left(\mathrm{C}_{5} \mathrm{H}_{5}\right)$ and two pseudotriplets $\left(\mathrm{C}_{5} \mathrm{H}_{4}\right.$, AA'XX' spin system, $\left.J=1.80 \mathrm{~Hz}\right)$ in each case (Experimental Section).

The structures of the diferrocenyl-substituted oligopyrroles $\mathbf{9 ,} \mathbf{1 6}$ and $\mathbf{2 0}$ in the solid state have been determined by single crystal X-ray diffraction analysis. Suitable crystals were obtained by diffusion of methanol (9 and 16) or toluene (20) into a dichloromethane solution containing the respective compound at ambient temperature. Important bond distances $(\AA)$, bond angles $\left(^{\circ}\right)$ and torsion angles $\left(^{\circ}\right)$ are summarized in the captions of Figures $1-3$, whilst crystal and structure refinement data are contained in the Experimental Section. The oligopyrroles crystallize in the triclinic space group $P-1$ (9 and 20) and in the monoclinic space group $P 2_{1} / c$ (16). In case of bipyrrole $\mathbf{9}$, the asymmetric unit contains two independent molecules. Each of the individual pyrrole heterocyclic moieties are essentially planar with rms deviations ranging from 0.0004-0.0066 ̊̊ (highest deviation observed for N1 (16) with 0.009(3) Å). Furthermore, electron delocalization within the individual pyrrole moieties can be inferred from the CC bond lengths, which fall between the distances of isolated single $\left(d_{C-C}^{0}=1.54 \AA^{28}\right)$ and double bonds $\left(d_{C=C}^{0}=1.34 \AA^{28}\right)$. The extent of delocalization can be expressed by calculating the 
parameter $\tau$ as normalized quotient of the single and double bond length (Equation 1). ${ }^{22}$ Completely delocalized systems such as benzene evince a $\tau$ value of 1 , while for localized systems $\tau$ approaches $0 .^{22}$ For the oligopyrroles average $\tau$ values of $0.799(\mathbf{9}), 0.878(\mathbf{1 6})$ and $0.803(\mathbf{2 0})$ were obtained, which are in the same range as for unsubstituted pyrrole $(0.830)^{29}$ and 2,3,4,5-tetraferrocenyl-1-phenyl-1H-pyrrole $(0.832)^{23}$.

$$
\tau=1+\frac{\left(d_{C-C} / d_{C=C}\right)-1}{1-\left(d_{C-C}^{0} / d_{C=C}^{0}\right)}
$$

a) $d_{C-C}^{0}=1.54 \AA, d_{C=C}^{0}=1.34 \AA, d_{C-C}=$ distance of the appropriate single bond, $d_{C=C}$ distance of the appropriate double bond.

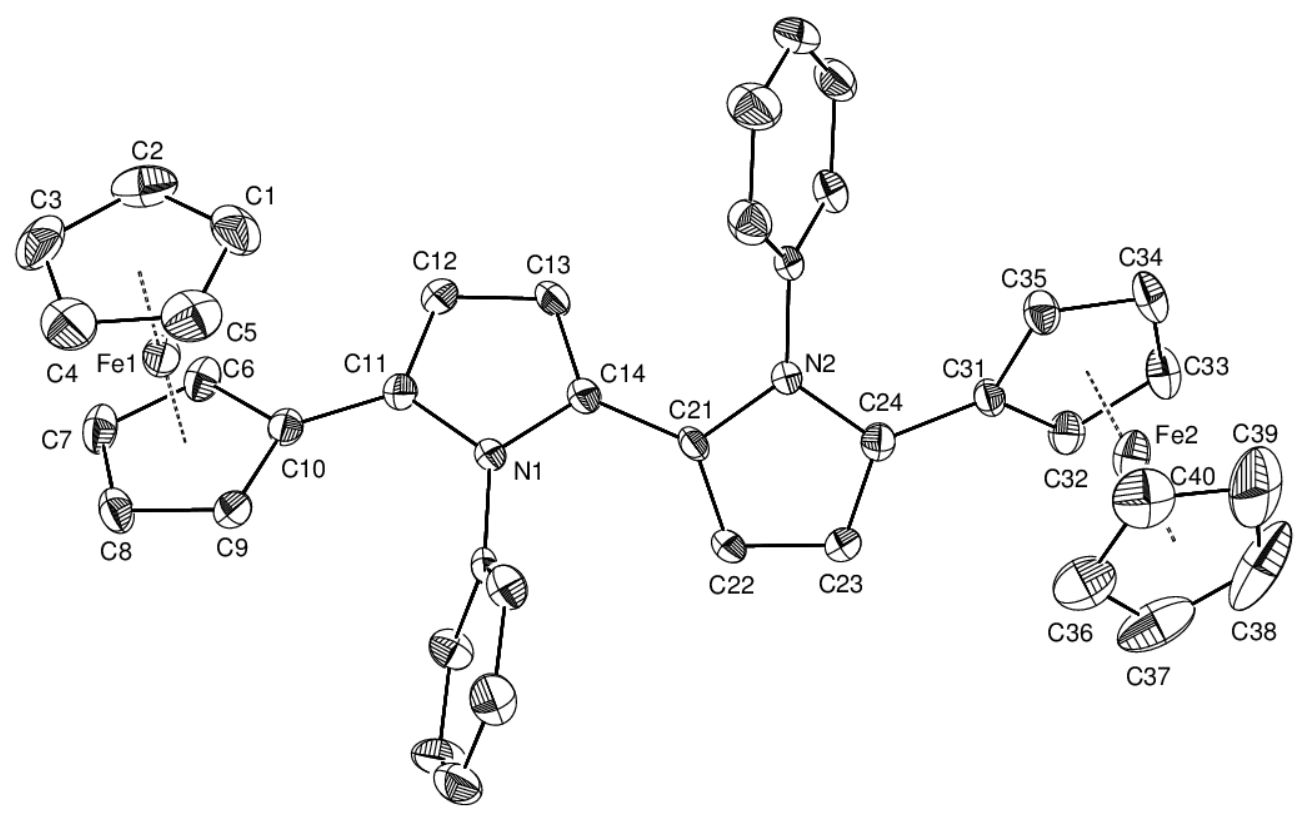

Figure 1. ORTEP diagram (50\% probability level) of the molecular structure of 9 with the atom numbering scheme. Hydrogen atoms have been omitted for clarity. Selected bond distances $(\AA)$, angles $\left(^{\circ}\right)$ and torsion angles $\left({ }^{\circ}\right)$ : average $\mathrm{D}-\mathrm{Fe}=1.647, \mathrm{~N} 1-\mathrm{C} 14=1.383(3), \mathrm{C} 11-\mathrm{C} 12=1.368(3), \mathrm{C} 12-\mathrm{C} 13=$ 1.396(3), C13-C14 = 1.370(3), C14-C21 = 1.462(3), C10-C11 = 1.464(3), C24-C31 = 1.467(3), N1$\mathrm{C} 15=1.436(3), \mathrm{N} 2-\mathrm{C} 25=1.423(3) ; \mathrm{C} 11-\mathrm{C} 12-\mathrm{C} 13=108.6(2), \mathrm{C} 11-\mathrm{N} 1-\mathrm{C} 14=108.7(2), \mathrm{N} 1-\mathrm{C} 14-$ $\mathrm{C} 21=122.5(2), \mathrm{N} 1-\mathrm{C} 11-\mathrm{C} 12=107.1(2)$, average $\mathrm{D}-\mathrm{Fe}-\mathrm{D}=178.3 ; \mathrm{N} 1-\mathrm{C} 14-\mathrm{C} 21-\mathrm{N} 2=-155.8(2)$, $\mathrm{C} 13-\mathrm{C} 14-\mathrm{C} 21-\mathrm{N} 2=33.9(4), \mathrm{C} 10-\mathrm{C} 11-\mathrm{N} 1-\mathrm{C} 15=1.0(4), \mathrm{C} 11-\mathrm{C} 12-\mathrm{C} 13-\mathrm{C} 14=-0.3(3), \mathrm{N} 1-\mathrm{C} 14-$ $\mathrm{C} 21-\mathrm{C} 22=36.1(4),\left(\mathrm{D}=\right.$ denotes the centroids of $\mathrm{C}_{5} \mathrm{H}_{4}$ and $\left.\mathrm{C}_{5} \mathrm{H}_{5}\right)$. 


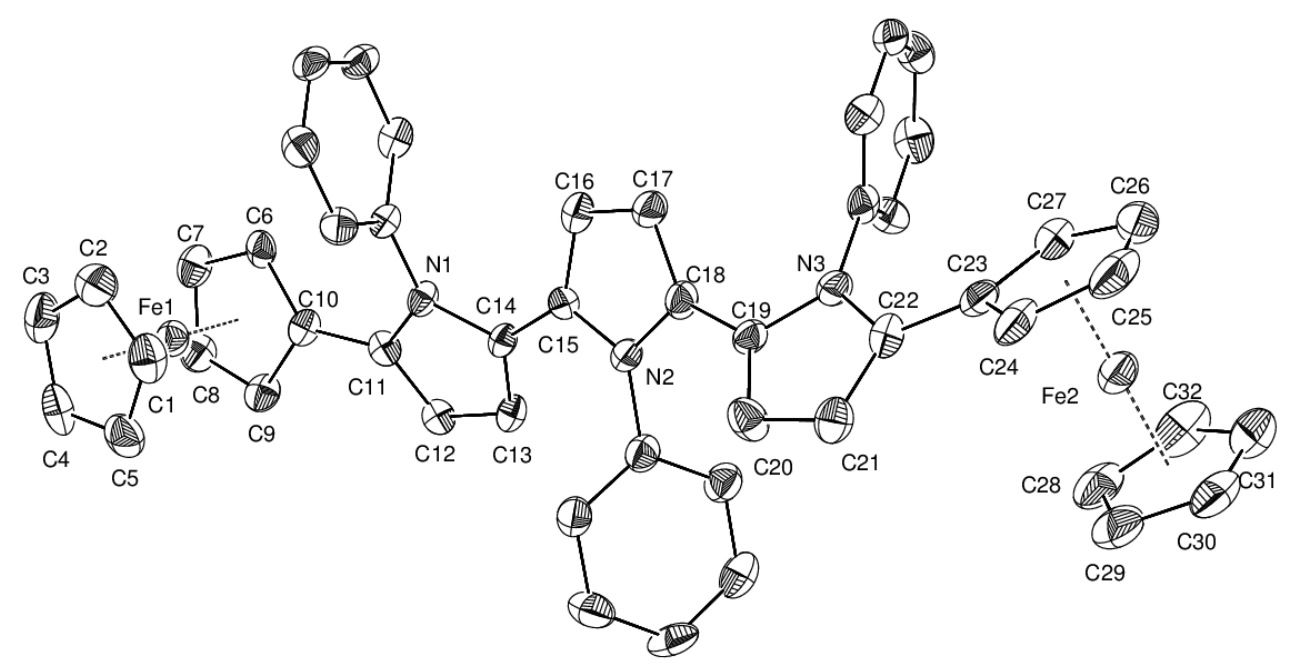

Figure 2. ORTEP diagram (50\% probability level) of the molecular structure of $\mathbf{1 6}$ with the atom numbering scheme. Hydrogen atoms and solvent molecules have been omitted for clarity. Selected bond distances $(\AA)$, angles $\left(^{\circ}\right)$ and torsion angles $\left(^{\circ}\right)$ : average $\mathrm{D}-\mathrm{Fe}=1.666, \mathrm{~N} 1-\mathrm{C} 33=1.426(7), \mathrm{N} 2-\mathrm{C} 39=$ 1.450(7), N3-C45 = 1.442(6), N1-C11 = 1.394(6), N1-C14 = 1.406(6), C11-C12=1.373(7), C12-C13 $=1.403(7), \mathrm{C} 13-\mathrm{C} 14=1.381(7), \mathrm{C} 10-\mathrm{C} 11=1.468(7), \mathrm{C} 14-\mathrm{C} 15=1.444(7), \mathrm{C} 18-\mathrm{C} 19=1.428(7)$, $\mathrm{C} 22-\mathrm{C} 23=1.447(7)$; average D-Fe-D = 177.5, C11-C12-C13 = 108.6(4), C11-N1-C14 = 108.8(4), $\mathrm{N} 2-\mathrm{C} 18-\mathrm{C} 29=123.7(5), \mathrm{C} 18-\mathrm{N} 2-\mathrm{C} 39=121.4(4), \mathrm{C} 10-\mathrm{C} 11-\mathrm{N} 1=125.8(5) ; \mathrm{N} 1-\mathrm{C} 14-\mathrm{C} 15-\mathrm{N} 2=$ 156.0(5), N2-C18-C19-N3 = 149.9(5), C10-C11-N1-C33 = 5.6(8), C11-C12-C13-C14 = 0.3(6), N1C14-C15-C16 = -26.3(8), $\left(\mathrm{D}=\right.$ denotes the centroids of $\mathrm{C}_{5} \mathrm{H}_{4}$ and $\left.\mathrm{C}_{5} \mathrm{H}_{5}\right)$.

In the solid state the oligopyrroles adopt a conformation in which the phenyl substituents point in different directions, in addition the pyrrole cores are not coplanar, as interplanar angles of 36.2(2), 34.0(2) (9), 27.2(3), 38.3(3) (16) and 83.1(1), 70.0(1), 77.7(2) ${ }^{\circ}(\mathbf{2 0})$ are observed. The CC bond distances between the ${ }^{c} \mathrm{C}_{4} \mathrm{~N}$ heterocycles are not affected by this torsion and are similar compared with related compounds. ${ }^{30,31}$ The ferrocenyl moieties in these compounds adopt an eclipsed conformation (4.9(2) Fe1, -3.2(3) Fe2, 6.0(3) Fe3, -9.3(3) Fe4 (9); 10.8(4) Fe1, 11.3(5) Fe2 (16); 4.2(3) Fe1, -1.1(8) $\left.{ }^{\circ} \mathrm{Fe} 2(\mathbf{2 0})\right)$ and are rotated by 21.1(1) (Fe1), 35.8(2) (Fe2) (9), 22.1(4) (Fe1), 27.9(3) (Fe2) (16), 9.8(3) $(\mathrm{Fe} 1)$ and $12.5(5)^{\circ}(\mathrm{Fe} 2)(\mathbf{2 0})$ out of the plane of the adjacent pyrrole. 


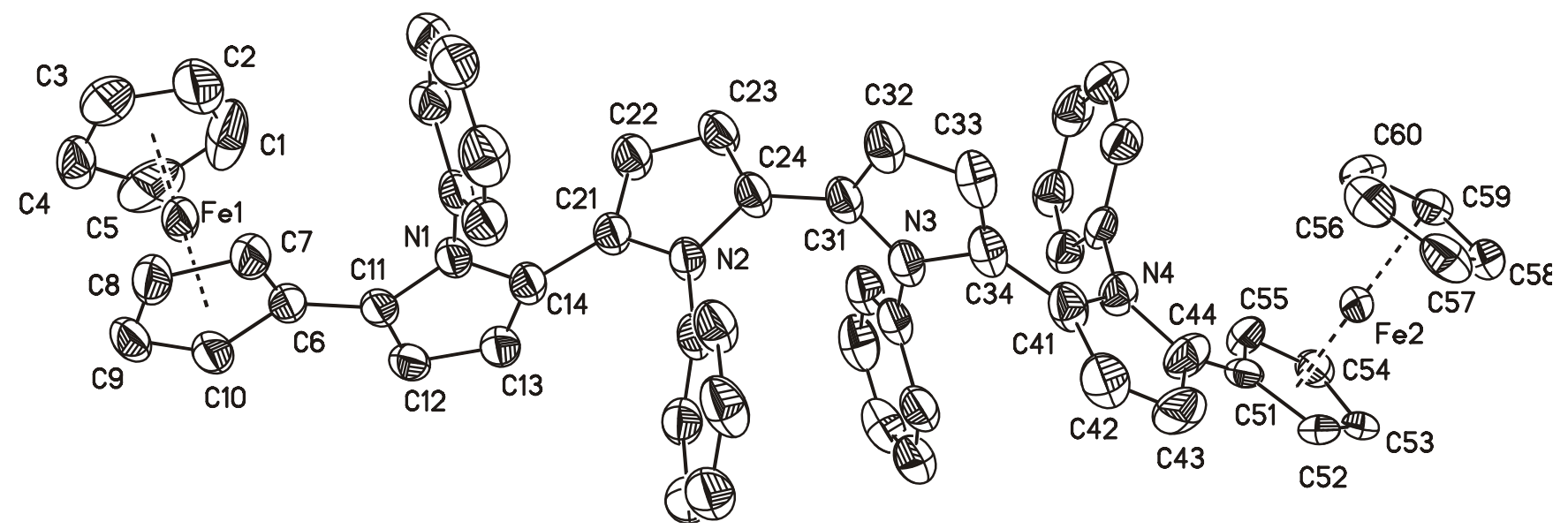

Figure 3. ORTEP diagram (50\% probability level) of the molecular structure of 20 with the atom numbering scheme. Hydrogen atoms have been omitted for clarity. Selected bond distances $(\AA)$, angles $\left(^{\circ}\right)$ and torsion angles $\left({ }^{\circ}\right)$ : average $\mathrm{D}-\mathrm{Fe}=1.653, \mathrm{~N} 1-\mathrm{C} 15=1.426(4), \mathrm{N} 2-\mathrm{C} 25=1.428(3), \mathrm{N} 3-\mathrm{C} 35=$ 1.417(4), N4-C45 = 1.432(3), C6-C11 = 1.453(4), C11-N1 = 1.391(4), C11-C12=1.374(4), C12-C13 $=1.411(4), \mathrm{C} 13-\mathrm{C} 14=1.366(4), \mathrm{C} 14-\mathrm{N} 1=1.394(4), \mathrm{C} 14-\mathrm{C} 21=1.474(4), \mathrm{C} 24-\mathrm{C} 31=1.475(4), \mathrm{C} 34-$ $\mathrm{C} 41=1.463(4), \mathrm{C} 44-\mathrm{C} 51=1.401(7)$; average D-Fe-D = 177.6, C11-C12-C13 = 108.1(3), C11-N1$\mathrm{C} 14=109.1(2), \mathrm{N} 2-\mathrm{C} 24-\mathrm{C} 31=123.1(2), \mathrm{N} 3-\mathrm{C} 34-\mathrm{C} 41=122.6(3), \mathrm{N} 4-\mathrm{C} 44-\mathrm{C} 51=129.9(5), \mathrm{C} 6-$ $\mathrm{C} 11-\mathrm{N} 1=125.1(3) ; \mathrm{C} 31-\mathrm{C} 32-\mathrm{C} 33-\mathrm{C} 34=0.0(3), \mathrm{N} 1-\mathrm{C} 14-\mathrm{C} 21-\mathrm{N} 2=98.9(3), \mathrm{N} 2-\mathrm{C} 24-\mathrm{C} 31-\mathrm{N} 3=$ 69.3(4), N3-C34-C41-N4 = 75.5(4), C7-C6-C11-N1 = -8.7(5), C35-N3-C34-C41 = -5.3(4), C43C44-C51-C55 = 166.5(7), $\left(\mathrm{D}=\right.$ denotes the centroids of $\mathrm{C}_{5} \mathrm{H}_{4}$ and $\left.\mathrm{C}_{5} \mathrm{H}_{5}\right)$.

\section{Electrochemistry}

The redox properties of oligopyrroles 7, 13 and 17 and diferrocenyl-substituted (oligo)pyrroles 4, 9, 16 and 20 have been determined by cyclic voltammetry, square-wave voltammetry (Figures 4 and 5) and the redox products studied further by UV-Vis/NIR spectroscopy using spectroelectrochemical techniques (Figures 6, 7; Supporting Information Figures SI1, SI2, SI4 and SI5). Dichloromethane solutions containing the analyte $\left(1.0 \mathrm{mmol} \cdot \mathrm{L}^{-1}\right)$ and $\left[\mathrm{N}^{n} \mathrm{Bu}_{4}\right]\left[\mathrm{B}\left(\mathrm{C}_{6} \mathrm{~F}_{5}\right)_{4}\right]\left(0.1 \mathrm{~mol} \cdot \mathrm{L}^{-1}\right)^{32}$ as supporting electrolyte were used for all measurements. The cyclic voltammetry measurements recorded at a scan rate of $100 \mathrm{mV} \cdot \mathrm{s}^{-1}$ are summarized in Table 1 . All redox potentials are referenced to the $\mathrm{FcH} / \mathrm{FcH}^{+}$ redox couple $\left(E^{\circ \prime}=0.00 \mathrm{mV}, \mathrm{FcH}=\mathrm{Fe}\left(\eta^{5}-\mathrm{C}_{5} \mathrm{H}_{5}\right)_{2}\right) .{ }^{33}$ 
Table 1. Cyclic voltammetry data (potentials $v s \mathrm{FcH} / \mathrm{FcH}^{+}$), scan rate $100 \mathrm{mV} \cdot \mathrm{s}^{-1}$ at a glassy-carbon electrode of $1.0 \mathrm{mmol} \cdot \mathrm{L}^{-1}$ solutions of the analytes in dry dichloromethane containing $0.1 \mathrm{~mol} \cdot \mathrm{L}^{-1}$ of $\left[\mathrm{N}^{n} \mathrm{Bu}_{4}\right]\left[\mathrm{B}\left(\mathrm{C}_{6} \mathrm{~F}_{5}\right)_{4}\right]$ as supporting electrolyte at $25^{\circ} \mathrm{C}$.

\begin{tabular}{ccccccc}
\hline Compd. & $\begin{array}{c}E_{1}^{\circ \prime}(\mathrm{mV})^{b} \\
\left(\Delta E_{\mathrm{p}}(\mathrm{mV})\right)^{c}\end{array}$ & $\begin{array}{c}E_{2}^{\circ \prime}(\mathrm{mV})^{b} \\
\left(\Delta E_{\mathrm{p}}(\mathrm{mV})\right)^{c}\end{array}$ & $\begin{array}{c}E_{3}^{\circ \prime}(\mathrm{mV})^{b} \\
\left(\Delta E_{\mathrm{p}}(\mathrm{mV})\right)^{c}\end{array}$ & $\begin{array}{c}E_{4}^{\circ \prime}(\mathrm{mV})^{b} \\
\left(\Delta E_{\mathrm{p}}(\mathrm{mV})\right)^{c}\end{array}$ & $\Delta E^{\circ \prime}(\mathrm{mV})^{d}$ & $K_{\mathrm{C}}{ }^{e}$ \\
\hline $\mathbf{4}^{a}$ & $-238(68)$ & $212(75)$ & - & - & 450 & $4.08 \cdot 10^{7}$ \\
$\mathbf{9}$ & $-250(74)$ & $70(74)$ & $810(74)$ & - & 320 & $2.58 \cdot 10^{5}$ \\
$\mathbf{1 6}$ & $-230(68)$ & $-65(74)$ & $480(74)$ & $1080(72)$ & 165 & $6.17 \cdot 10^{2}$ \\
$\mathbf{2 0}$ & $-175(90)$ & $265(66)$ & $725(63)$ & - & - & -
\end{tabular}

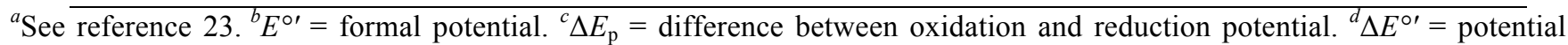
difference between the two ferrocenyl related redox processes. ${ }^{e} K_{\mathrm{C}}=$ comproportionation constant.

Figure 4 shows the cyclic and square wave voltammograms of diferrocenyl (oligo)pyrroles 4, 9, 16 and 20. The ferrocenyl units of $\mathbf{4 , 9}$ and $\mathbf{1 6}$ are oxidized subsequently, while for $\mathbf{2 0}$ one reversible redox process was observed. The relatively high $\Delta E_{\mathrm{p}}$ value $(90 \mathrm{mV})$ and the larger $I_{\mathrm{c}, \mathrm{p}}$ and $I_{\mathrm{c}, \mathrm{a}}$ values of this redox event (Figure 4) indicate that two individual oxidation processes take place in a close potential range and hence are not resolved. ${ }^{34}$ Due to the increasing chain length and therefore, the larger metalmetal distance, the redox splitting $\Delta E^{\circ \prime}$ between the ferrocenyl moieties decreases from $450 \mathrm{mV}$ (4) to $320 \mathrm{mV}(\mathbf{9})$ to $165 \mathrm{mV}(\mathbf{1 6})$ (Table 1$)$, and the corresponding comproportionation constants $K_{\mathrm{C}}(\mathrm{R} \cdot \mathrm{T} \cdot \mathrm{ln}$ $K_{\mathrm{C}}=\Delta E^{\circ} \cdot \mathrm{F}$ ) have been determined (Table 1$) .{ }^{35}$ The larger $K_{\mathrm{C}}$ values are indicative for the high thermodynamic stability of the mixed-valent species with respect to disproportionation. Hence these molecules are suitable for spectroelectrochemical investigations (vide infra) as the chemical equilibrium (Equation 2) favors the mixed-valent form of the mono-oxidized compounds.

$$
K_{C}=\frac{\left[M_{1}^{n} M_{2}^{n+1}\right]^{2}}{\left[M_{1}^{n} M_{2}^{n}\right]\left[M_{1}^{n+1} M_{2}^{n+1}\right]}=e^{\frac{\Delta E^{\circ} \cdot F}{R T}}
$$



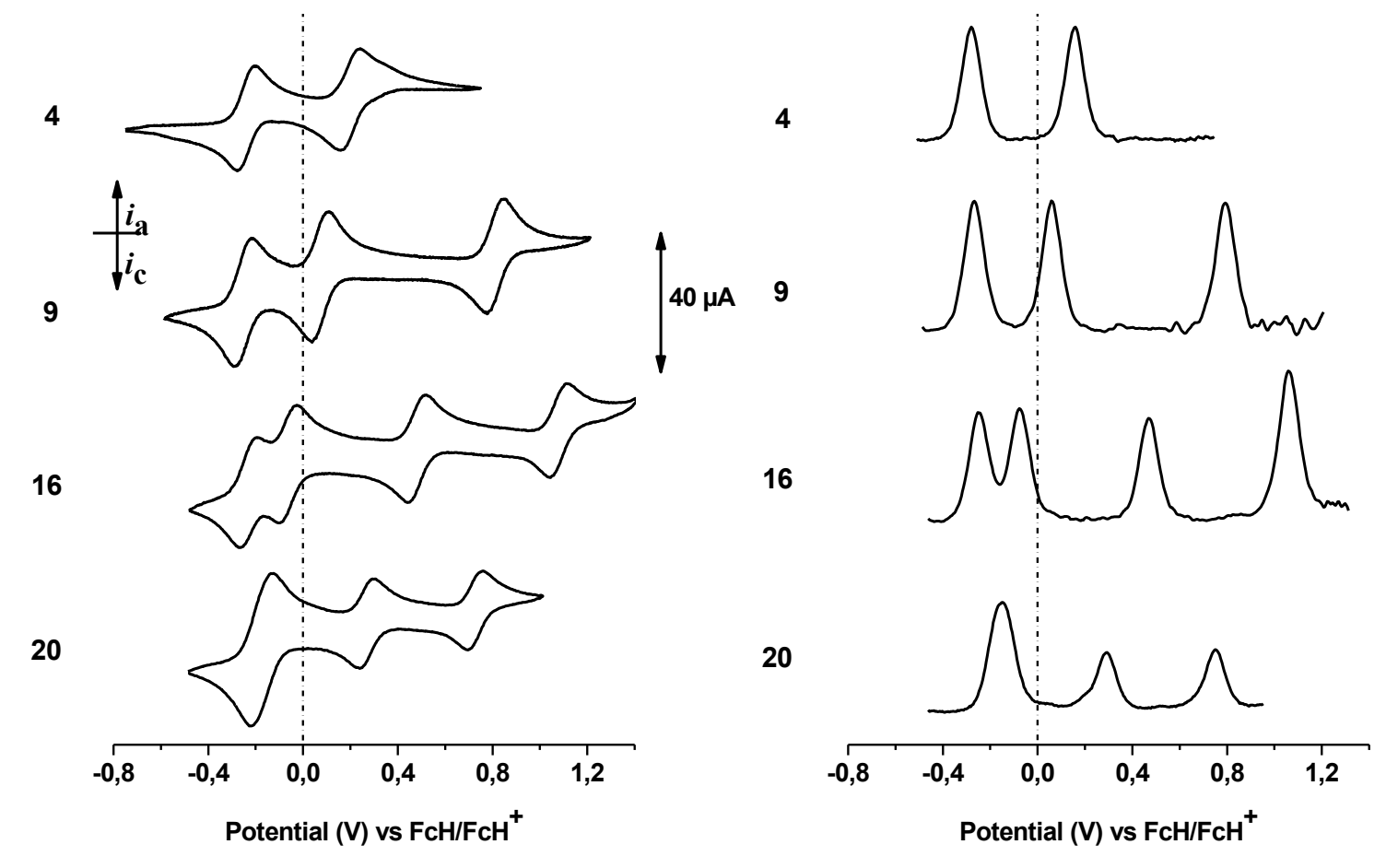

Figure 4. Voltammograms of dichloromethane solutions containing $1.0 \mathrm{mmol} \cdot \mathrm{L}^{-1}$ of diferrocenyl (oligo)pyrrole 4, 9, 16 and 20 at $25{ }^{\circ} \mathrm{C}$. Supporting electrolyte $\left[\mathrm{N}\left({ }^{n} \mathrm{Bu}\right)_{4}\right]\left[\mathrm{B}\left(\mathrm{C}_{6} \mathrm{~F}_{5}\right)_{4}\right]\left(0.1 \mathrm{~mol} \cdot \mathrm{L}^{-1}\right)$. Left: Cyclic voltammograms (scan rate: $100 \mathrm{mV} \cdot \mathrm{s}^{-1}$ ). Right: Square-wave voltammograms (scan rate: $\left.1 \mathrm{mV} \cdot \mathrm{s}^{-1}\right)$.

In constrast to the oligo(pyrrole) bridged bis(ferrocene) complexes $\mathbf{4 , 9}$ and 16, the analogous thiophene systems showed little or no redox splitting between the terminal ferrocenyl units $\left(\Delta E^{\circ \prime}=260\right.$ $\mathrm{mV}$ (2,5-diferrocenyl thiophene, dichloromethane, $\left[\mathrm{N}\left({ }^{n} \mathrm{Bu}\right)_{4}\right]\left[\mathrm{B}\left(\mathrm{C}_{6} \mathrm{~F}_{5}\right)_{4}\right]$ as supporting electrolyte $)^{22}$; $\Delta E^{\circ \prime}=130 \mathrm{mV}\left(5,5^{\prime}\right.$-diferrocenyl-2,2'-bithiophene, dichloromethane, $\left[\mathrm{N}\left({ }^{n} \mathrm{Bu}\right)_{4}\right]\left[\mathrm{B}\left(\mathrm{C}_{6} \mathrm{H}_{3}\left(\mathrm{CF}_{3}\right)_{2}\right)_{4}\right]$ as supporting electrolyte) ${ }^{16,36}$ ). The group of Sato has synthesized related ter-, quarter-, quinque-, and sexithiophenes (substituted in position 3 with hexyl or methoxy groups to increase the solubility) with terminal ferrocenyl moieties to create model systems for molecular wires, but these complexes also exhibited little or no separation of the ferrocene-based redox processes..$^{20,21}$ It seems likely that the larger redox splitting in the ferrocenyl-functionalized pyrroles 4,9 and 16 is caused by the smaller energy gap between the ferrocenyl moieties and the heterocyclic bridging moiety as well as the larger delocalization 
of the pyrrole unit itself..$^{23}$ Therefore, the oligopyrroles may provide a more effective conduit for intermetallic charge transfer between the ferrocene units through the $\pi$-conjugated backbone.

In addition to the ferrocenyl-related redox events, at higher potential the oxidation of the pyrrole units could be observed for $\mathbf{9}, \mathbf{1 6}$ and $\mathbf{2 0}$. With increasing length of the pyrrolic $\pi$-system this oxidation process is shifted to cathodic potentials. This behavior is not unexpected as shown on the example of extended $\pi$-systems such as benzene, naphthalene and anthracene for which a similar potential shift could be observed..$^{37,38}$ To verify the assignment of these additional redox events, electrochemical measurements of the non-ferrocenyl substituted oligopyrroles 7, $\mathbf{1 3}$ and $\mathbf{1 7}$ have been carried out (Figure 5, Table 2).

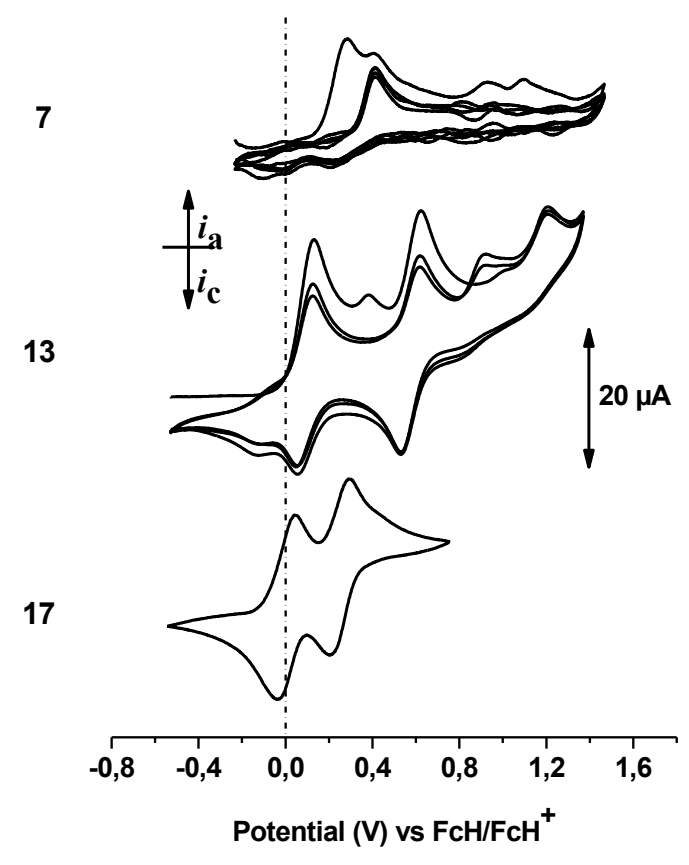

Figure 5. Cyclic voltammograms (scan rate: $100 \mathrm{mV} \cdot \mathrm{s}^{-1}$ ) of dichloromethane solutions containing 1.0 mmol $\mathrm{L}^{-1}$ of oligopyrrole 7,13 and 17 at $25{ }^{\circ} \mathrm{C}$. Supporting electrolyte $\left[\mathrm{N}\left({ }^{n} \mathrm{Bu}\right)_{4}\right]\left[\mathrm{B}\left(\mathrm{C}_{6} \mathrm{~F}_{5}\right)_{4}\right](0.1 \mathrm{~mol} \cdot$ $\left.\mathrm{L}^{-1}\right)$.

The first cycle in the voltammogram of bipyrrole 7 shows four irreversible oxidation processes, while further cycles give only an irreversible oxidation wave at $400 \mathrm{mV}$. This chemical behavior is not unexpected as upon oxidation a reactive radical cation is formed and polymerization as well as other 
side reactions can occur easily through the 5 and $5^{\prime}$ positions. In contrast, the cyclic voltammogram of the di(trimethylsilyl)-substituted quarterpyrrole 17 shows two well-separated reversible one-electron redox processes with a potential difference of $\Delta E^{\circ \prime}=200 \mathrm{mV}$, which is stable over more than 10 cycles. Extension of the oligo(pyrrole) $\pi$-system leads to the stabilization of the radical cation and suppresses the decomposition.

Table 2. Cyclic voltammetric data (potentials $v s \mathrm{FcH} / \mathrm{FcH}^{+}$), scan rate $100 \mathrm{mV} \cdot \mathrm{s}^{-1}$ at a glassy-carbon electrode of $1.0 \mathrm{mmol} \cdot \mathrm{L}^{-1}$ solutions of the analytes in dry dichloromethane containing $0.1 \mathrm{~mol} \cdot \mathrm{L}^{-1}$ of $\left[\mathrm{N}^{n} \mathrm{Bu}_{4}\right]\left[\mathrm{B}\left(\mathrm{C}_{6} \mathrm{~F}_{5}\right)_{4}\right]$ as supporting electrolyte at $25^{\circ} \mathrm{C}$.

\begin{tabular}{|c|c|c|c|c|c|}
\hline Compd. & $\begin{array}{c}E_{1}^{\mathrm{o \prime}}(\mathrm{mV})^{a} \\
\left(\Delta E_{\mathrm{p}}(\mathrm{mV})\right)^{b}\end{array}$ & $\begin{array}{c}E_{2}^{\mathrm{o}}(\mathrm{mV})^{a} \\
\left(\Delta E_{\mathrm{p}}(\mathrm{mV})\right)^{b}\end{array}$ & $\begin{array}{c}E_{3}^{\circ \prime}(\mathrm{mV})^{a} \\
\left(\Delta E_{\mathrm{p}}(\mathrm{mV})\right)^{b}\end{array}$ & $\begin{array}{c}E_{4}^{\mathrm{o} \prime}(\mathrm{mV})^{a} \\
\left(\Delta E_{\mathrm{p}}(\mathrm{mV})\right)^{b}\end{array}$ & $\Delta E_{1}^{\circ \prime}(\mathrm{mV})^{c}$ \\
\hline 7 & $280(-)$ & $400(-)$ & $930(-)$ & $1095(-)$ & - \\
\hline 13 & $120(-)$ & $605(-)$ & $905(-)$ & $1190(-)$ & - \\
\hline 17 & $5(80)$ & $205(90)$ & - & - & 200 \\
\hline
\end{tabular}

A comparison with other unsubstituted oligopyrroles reported in the literature is difficult because the cyclic voltammetry data have been determined under different measurement conditions (acetonitrile and $\left[\mathrm{NEt}_{4}\right]\left[\mathrm{BF}_{4}\right]$ as supporting electrolyte). Hapiot et al. could detect one irreversible redox event for the bipyrrole $\left(E^{\circ \prime}=600 \mathrm{mV}\right)$ and for the terpyrrole $\left(E^{\circ \prime}=280 \mathrm{mV}\right)$, while for the quarterpyrrole two reversible redox processes $\left(E_{1}^{\circ \prime}=160 \mathrm{mV}, E_{2}^{\circ \prime}=430 \mathrm{mV}\right)$ with a $\Delta E^{\circ \prime}$ value compatible to or measurements $(170 \mathrm{mV})$ was observed..$^{39}$ Depending on the supporting electrolyte a different number of redox processes and varying potential differences was found. It could also be shown that the use of different electrolytes has a significant impact on the position and reversibility of the redox potentials, which has already been discussed in the literature. ${ }^{17,23,40,41}$ In comparison to the ferrocenyl-substituted analoga 9, 16 and 20 the pyrrole-related oxidation is shifted to cathodic potentials. The ferrocenyl moieties of $\mathbf{9 , 1 6}$ and $\mathbf{2 0}$ are oxidized at lower potential than the appropriate oligopyrrole backbone, 
therefore the thus formed ferrocenium units act as electron withdrawing substituents hindering the oxidation of the heterocyle.

\section{Spectroelectrochemistry}

The spectroelectrochemical studies were performed by stepwise increase of the potential (step heights: $25 \mathrm{mV}, 50 \mathrm{mV}$ or $100 \mathrm{mV}$ ) from -200 to $1000 \mathrm{mV} v s \mathrm{Ag} / \mathrm{AgCl}$ in an OTTLE (Optically Transparent Thin-Layer Electrochemistry) cell ${ }^{42}$ in dichloromethane solutions of $4,^{23} \mathbf{9}, \mathbf{1 6}, 17$ and 20 $\left(0.002 \mathrm{~mol} \cdot \mathrm{L}^{-1}\right)$ containing $\left[\mathrm{N}^{n} \mathrm{Bu}_{4}\right]\left[\mathrm{B}\left(\mathrm{C}_{6} \mathrm{~F}_{5}\right)_{4}\right]\left(0.1 \mathrm{~mol} \cdot \mathrm{L}^{-1}\right)$ as electrolyte at $25{ }^{\circ} \mathrm{C}$. The stepwise increase of the potential allows, starting from the neutral (oligo)pyrroles 4, 9, 16, 17 and 20, the in situ generation of cationic $4^{n+23}, \mathbf{9}^{n+}, \mathbf{1 6}^{n+}, \mathbf{1 7}^{n+}$ and $\mathbf{2 0}^{(n+1)+}(n=1,2)$ (Figure 6; Supporting Information Figures SI1, SI2, SI4 and SI5).
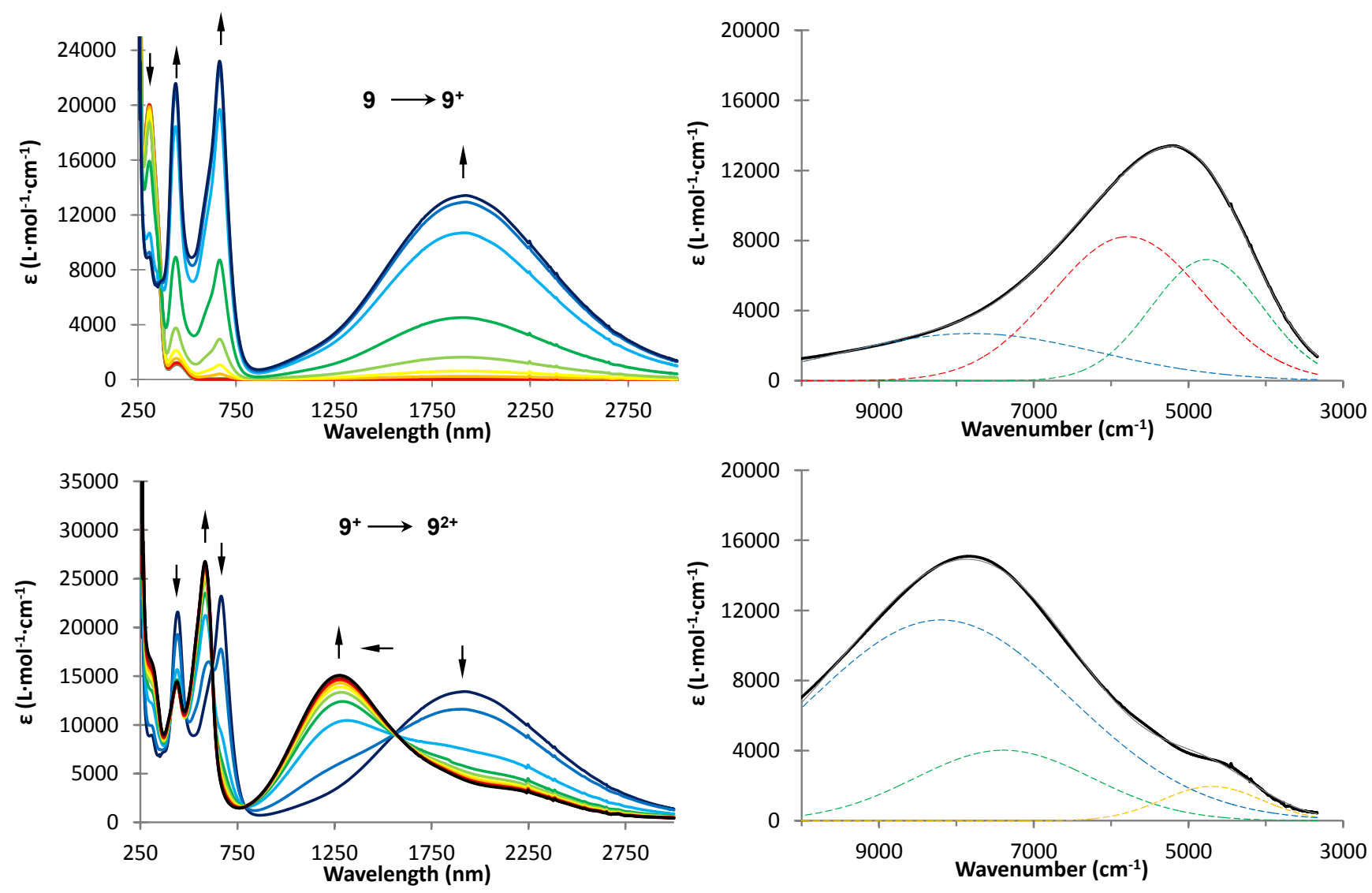

Figure 6. UV-Vis/NIR spectra of 9 at rising potentials $v s \mathrm{Ag} / \mathrm{AgCl}:-200$ to $350 \mathrm{mV}$ (left top), 350 to $1000 \mathrm{mV}$ (left bottom). Right: deconvolution of the NIR absorption at $350 \mathrm{mV}$ (top) of in situ generated $\mathbf{9}^{+}$and at $900 \mathrm{mV}$ (bottom) of in situ generated $\mathbf{9}^{2+}$ using three Gaussian-shaped bands. Measurement conditions: $25^{\circ} \mathrm{C}$, dichloromethane, $0.1 \mathrm{~mol} \cdot \mathrm{L}^{-1}\left[\mathrm{~N}^{n} \mathrm{Bu} 4\right]\left[\mathrm{B}\left(\mathrm{C}_{6} \mathrm{~F}_{5}\right)_{4}\right]$ as supporting electrolyte. 
The NIR data of $\mathbf{4}$ and its analysis has been published elsewhere. ${ }^{23}$ Upon oxidation, diferrocenyl bipyrrole 9 shows an increasing absorption in the NIR region at $2000 \mathrm{~nm}$, which can be assigned to a CT (Charge Transfer) transition of the mixed-valent species $\mathbf{9}^{+}$. A further increase of the potential leads to the collapse of this absorption envelope and new bands at $1200 \mathrm{~nm}$ assigned to a LMCT (Ligand-to-

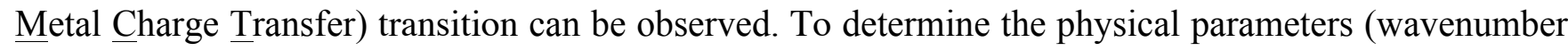
$\left(v_{\max }\right)$, extinction $\left(\varepsilon_{\max }\right)$, Full-Width-at-Half-Maximum $\left.(=\mathrm{FWHM})\left(\Delta v_{1 / 2}\right)\right)$ of the charge transfer excitations in the NIR region, deconvolution assuming Gaussian shaped bands has been applied (Table $3)$.

Surprisingly upon enlargement of the pyrrolic chain the characteristics of the charge transfer absorptions change. Mixed valent $\mathbf{9}^{+}$and $\mathbf{1 6}^{+}$showed much more intense absorptions and a shift of the excitation maxima towards higher energy. Deconvolution of the charge transfer bands in $\mathbf{9}^{+}$and $\mathbf{1 6}^{+}$ revealed that three bands contribute to the absorption in the NIR region for both compounds (Table 3, Figure 6, Figure SI1). None of these transitions showed typical characteristics ${ }^{43,44}$ of an IVCT (= InterValence $\underline{\text { Charge }}$ Transfer) excitation and are much more intense than the IVCT band found in $\mathbf{4}^{+23}$. Therefore, it might be concluded that the classical two state model is not applicable to the elongated pyrrole systems $(\mathbf{9}, \mathbf{1 6})$, a more complex charge transfer behavior is observed. Especially for the terpyrrole $\mathbf{1 6}^{+}$the characteristics of the CT absorption in the NIR resembles the one for dicationic $\mathbf{1 6}^{2+}$ pointing to a strong involvement of LMCT and inter-bridge-charge transfer interactions. 
Table 3. NIR data of the diferrocenyl (oligo)pyrroles $4^{n+}, \mathbf{9}^{n+}, \mathbf{1 6}^{n+}$ and $\mathbf{2 0}^{(n+1)+}(n=1,2){ }^{a}$

Compd. transition $v_{\max }\left(\mathrm{cm}^{-1}\right) \quad \varepsilon_{\max }\left(\mathrm{L} \cdot \mathrm{mol}^{-1} \cdot \mathrm{cm}^{-1}\right) \quad \Delta v_{1 / 2}\left(\mathrm{~cm}^{-1}\right)$

\begin{tabular}{ccccc}
\hline $\mathbf{4}^{+\boldsymbol{b}}$ & LMCT & 4256 & 1805 & 690 \\
$\mathbf{4}^{\mathbf{2 +}}$ & IVCT & 4820 & 4200 & 2369 \\
& LMCT & 8500 & 190 & 900 \\
$\mathbf{9}^{+}$ & LMCT & 9900 & 1500 & 3400 \\
& CT & 4800 & 6900 & 1700 \\
& CT & 5800 & 8200 & 2300 \\
$\mathbf{9}^{\mathbf{2}}$ & CT & 7800 & 2700 & 3850 \\
& LF & 4700 & 1950 & 1500 \\
& CT & 8200 & 11400 & 3900 \\
$\mathbf{1 6}^{+}$ & CT & 7400 & 4000 & 2700 \\
& CT & 5400 & 10700 & 2100 \\
& CT & 6650 & 7450 & 2700 \\
$\mathbf{1 6}^{2+}$ & CT & 9100 & 3600 & 4050 \\
& CT & 6200 & 11750 & 2800 \\
$\mathbf{2 0}^{\mathbf{2 +}}$ & CT & 8050 & 19900 & 3800 \\
& CT & 5900 & 17600 & 2500 \\
& CT & 7800 & 21350 & 3600
\end{tabular}

${ }^{a}$ In dry dichloromethane containing $0.1 \mathrm{~mol} \cdot \mathrm{L}^{-1}$ of $\left[\mathrm{N}^{n} \mathrm{Bu}_{4}\right]\left[\mathrm{B}\left(\mathrm{C}_{6} \mathrm{~F}_{5}\right)_{4}\right]$ as supporting electrolyte at $25{ }^{\circ} \mathrm{C} .{ }^{b}$ See reference 23 . ${ }^{c}$ Ligand field transition.

Due to the large metal-metal distance, mixed-valent $\mathbf{2 0}^{+}$showed no coupling between its redox-active moieties and is thermodynamically not stable under the applied conditions and hence the ferrocenyl termini in diferrocenyl quarterpyrrole are oxidized simultaneously. Therefore, the electronic character of the mixed-valent species cannot be determined by NIR spectroscopy. Nevertheless, $\mathbf{2 0}^{\mathbf{2 +}}$ and $\mathbf{2 0}^{\mathbf{3 +}}$ were in situ generated within the NIR measurement setup (Figure SI2) showing remarkably intense LMCT absorptions in the spectral range between 1250 and $1700 \mathrm{~nm}$. To prove the character of these absorptions their solvatochromic behavior was studied using solvents with different polarities (dichloromethane $\left(\varepsilon^{o}=0.42\right)$, tetrahydrofuran $\left(\varepsilon^{\mathrm{o}}=0.45\right)$, acetonitrile $\left.\left(\varepsilon^{\mathrm{o}}=0.65\right)\right) .^{45}$ The thus observed solvatochromic shifts were negligible $(<100 \mathrm{~nm})$ and proved the solvent independency of this charge transfer process (Figure SI3). A deconvolution of the NIR spectrum of $\mathbf{2 0}^{\mathbf{2 +}}$ gives two large Gaussian- 
shaped functions at $5900 \mathrm{~cm}^{-1}\left(\Delta v_{1 / 2}=2500 \mathrm{~cm}^{-1} ; \varepsilon_{\max }=17600 \mathrm{~L} \cdot \mathrm{mol}^{-1} \cdot \mathrm{cm}^{-1}\right)$ and $7800 \mathrm{~cm}^{-1}\left(\Delta v_{1 / 2}=\right.$ $\left.3600 \mathrm{~cm}^{-1} ; \varepsilon_{\max }=21350 \mathrm{~L} \cdot \mathrm{mol}^{-1} \cdot \mathrm{cm}^{-1}\right)$. Comparison with the spectroelectrochemical measurements of $4^{2+}, 9^{2+}$ and $16^{2+}$ showed that these compounds also exhibit weak to strong LMCT bands in a range between 1000 and $1740 \mathrm{~nm}$. Extension of the oligo(pyrrole) $\pi$-system leads to a bathochromic shift of these LMCT transitions, while simultaneously increasing their intensity (Figure 7). With a decrease of the potential gap (Electrochemical Part Table 1, Figure 4) between the second ferrocenyl-related redox process and the first pyrrolic oxidation, the acceptor orbitals, within a ligand-to-metal charge transfer process, are raised, while the donor orbitals are lowered in energy. This results in a lower optical transition energy and thus a bathochromic shift. A comparable phenomenon has been described by Zhu and Wolf on the example of various ethynyl-ferrocenyl (oligo-)thiophenes. ${ }^{46}$ They could show that a longer thiophene chain leads to a decreased energy difference between the ferrocenyl centered acceptor orbital and the thiophenic donor orbitals. ${ }^{46}$ The different behavior of $\mathbf{4}^{\mathbf{2 +}}$ in comparison to $\mathbf{9}^{\mathbf{2 +}}, \mathbf{1 6}^{\mathbf{2 +}}$ and $\mathbf{2 0}^{\mathbf{2 +}}$ again points to an involvement of inter-bridge charge transfer excitations for the elongated pyrroles, while $\mathbf{4}^{2+}$ cannot possess such absorptions.

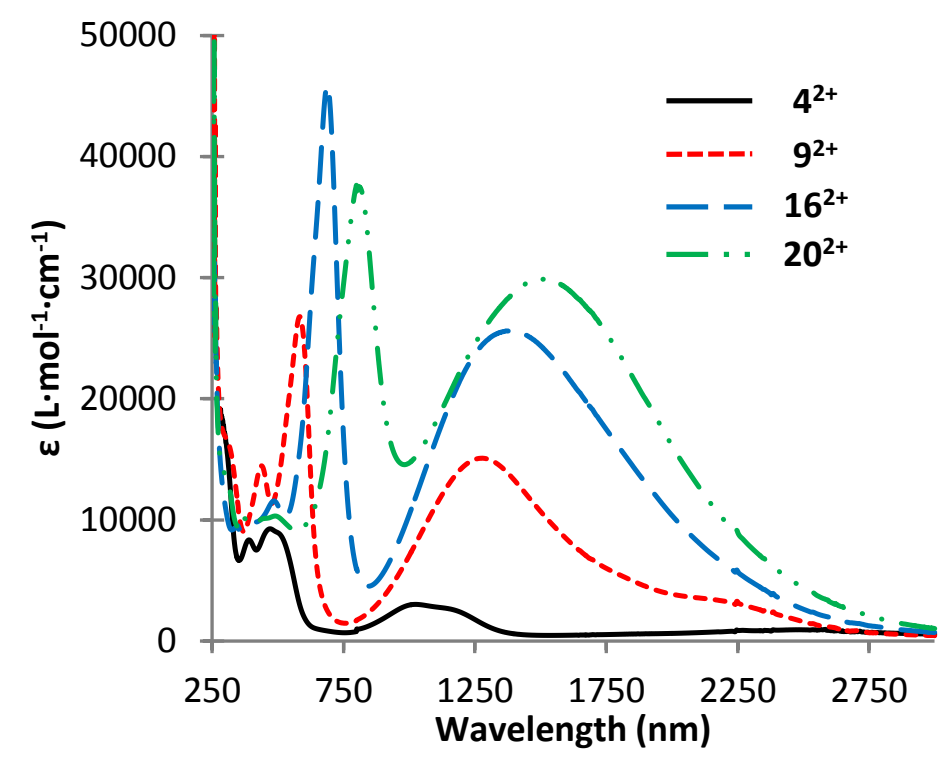

Figure 7. Bathochromic shift of the NIR spectra of $4^{2+}, \mathbf{9}^{2+}, \mathbf{1 6}^{2+}$ and $\mathbf{2 0}^{2+}\left(0.002 \mathrm{~mol} \cdot \mathrm{L}^{-1}\right.$ in dichloromethane) at $25^{\circ} \mathrm{C}$, supporting electrolyte $\left[\mathrm{N}^{n} \mathrm{Bu}_{4}\right]\left[\mathrm{B}\left(\mathrm{C}_{6} \mathrm{~F}_{5}\right)_{4}\right]\left(0.1 \mathrm{~mol} \cdot \mathrm{L}^{-1}\right)$. 
For comparison, the potential-depended UV-Vis/NIR spectra of 5,5"'-di(trimethylsilyl) quarterpyrrole (17) have been measured (Figure SI5). While no absorption could be found in a similar spectral region to the LMCT absorption, intense $\pi-\pi^{*}$ absorptions below $1250 \mathrm{~nm}$ can be observed. Those sharp and intense bands could also be found in $\mathbf{9}^{\mathbf{2 +}}(624 \mathrm{~nm}), \mathbf{1 6}^{\mathbf{2 +}}(696 \mathrm{~nm})$ and $\mathbf{2 0}^{\mathbf{2 +}}(830 \mathrm{~nm})$. For $\mathbf{4 ,} \mathbf{9}$ and 16 $(\mathrm{SI} 2){ }^{1} \mathrm{~A}_{1 \mathrm{~g}} \rightarrow{ }^{1} \mathrm{E}_{\mathrm{lg}}$ and ${ }^{1} \mathrm{~A}_{\mathrm{lg}} \rightarrow{ }^{1} \mathrm{E}_{2 \mathrm{~g}} d-d$ transitions of the ferrocenyl substituents ${ }^{47}$ (465 and $650 \mathrm{~nm}$ (4), 450 and $670 \mathrm{~nm}(\mathbf{9}), 520$ and $810 \mathrm{~nm}(\mathbf{1 6}))$ can be detected in the UV-Vis region, which are shifted bathochromically compared to ferrocene $(322$ and $437 \mathrm{~nm}) .{ }^{48}$ A bathochromic shift of the $d-d$ transitions with increasing chain length of the (oligo)pyrroles can be seen indicating that less energy is necessary for these excitations. ${ }^{49}$

\section{CONCLUSION}

A series of diferrocenyl-substituted (oligo)pyrroles 4, 9, 16 and 20 could be synthesized using palladium-catalyzed Negishi $C, C$ cross-coupling reactions. Single crystal X-ray diffraction analysis of diferrocenyl bipyrrole (9), terpyrrole (16) and quarterpyrrole (20) show a decrease in coplanarity in the heterocyclic chain with growing number of pyrrole units. The redox behavior of the title compounds have been investigated by electrochemical methods such as cyclic voltammetry and square wave voltammetry. While the ferrocenyl moieties in quarterpyrrole $\mathbf{2 0}$ are oxidized simultaneously, the terminal units of pyrroles $\mathbf{4 , 9}$ and 16 show a redox splitting of $450 \mathrm{mV}(\mathbf{4}), 320 \mathrm{mV}(\mathbf{9})$ and $165 \mathrm{mV}$ (16) in the cyclic and square wave voltammograms. Additionally, one (9) or two (16 and 20) pyrrolerelated well-defined reversible one-electron redox processes were observed. The metal-metal communication was further proven by UV-Vis/NIR spectroelectrochemical measurements, which showed absorptions in the NIR region. The characteristics of these absorptions have been analyzed by deconvolution calculations and solvatochromic experiments. While Mixed-valent compound $\mathbf{4}^{+}$possess intense IVCT absorptions, the classical two state model seems not to be applicable to the longer 
oligopyrroles $\left(\mathbf{9}^{+}, \mathbf{1 6}^{+}\right)$. Diferrocenyl (oligo)pyrroles showed weak (4) to intense (9, 16 and 20) CT absorptions in the dicationic oxidation state. In a good agreement with other published examples ${ }^{46}$ those bands showed a bathochromic shift, when the chain length of the backbone is increased.

\section{EXPERIMENTAL SECTION}

General conditions. All reactions were carried out under an atmosphere of nitrogen using standard Schlenk techniques. Tetrahydrofuran, $n$-hexane and $n$-pentane were purified by distillation from sodium/benzophenone ketyl, toluene and diethyl ether were purified by distillation from sodium. Dichloromethane and $\mathrm{N}, \mathrm{N}$-dimethylformamide were purified by distillation from calcium hydride.

Reagents. ${ }^{n} \mathrm{BuLi}\left(2.5 \mathrm{M}\right.$ solution in $n$-hexane), ${ }^{t} \mathrm{BuLi}$ (1.6 M solution in $n$-pentane), ferrocene, $\mathrm{KO}{ }^{t} \mathrm{Bu}, N$ phenylpyrrole, $N$-bromosuccinimide, trimethylsilyl chloride and tetra- $n$-butylammonium fluoride were purchased from commercial suppliers and used without further purification. 2-Bromo- $N$-phenylpyrrole (1), 2,5-dibromo- $N$-phenylpyrrole $(2)^{25}$ and $\left[\mathrm{N}\left({ }^{n} \mathrm{Bu}\right)_{4}\right]\left[\mathrm{B}\left(\mathrm{C}_{6} \mathrm{~F}_{5}\right)_{4}\right]^{50}$ were prepared according to published procedures. $\left[\mathrm{ZnCl}_{2} \cdot 2 \mathrm{THF}\right]$ was received by drying $\mathrm{ZnCl}_{2}$ with thionyl dichloride and additional reaction with dry tetrahydrofuran. The palladium catalyst $\left[\mathrm{P}\left({ }^{t} \mathrm{C}_{4} \mathrm{H}_{9}\right)_{2} \mathrm{C}\left(\mathrm{CH}_{3}\right)_{2} \mathrm{CH}_{2} \mathrm{Pd}(\mu-\mathrm{Cl})\right]_{2}$ was synthesized according to Clark et al. ${ }^{26}$

Instruments. ${ }^{1} \mathrm{H}$ NMR $(500.3 \mathrm{MHz})$ and ${ }^{13} \mathrm{C}\left\{{ }^{1} \mathrm{H}\right\}$ NMR $(125.8 \mathrm{MHz})$ spectra were recorded with a Bruker Avance III 500 spectrometer operating at $298 \mathrm{~K}$ in the Fourier transform mode. Chemical shifts are reported in $\delta$ (parts per million) using undeuterated solvent residues as internal standard (chloroform- $d_{3}:{ }^{1} \mathrm{H}$ at $7.26 \mathrm{ppm}$ and ${ }^{13} \mathrm{C}\left\{{ }^{1} \mathrm{H}\right\}$ at $77.16 \mathrm{ppm}$; acetone- $d_{6}:{ }^{1} \mathrm{H}$ at $2.05 \mathrm{ppm}$ and ${ }^{13} \mathrm{C}\left\{{ }^{1} \mathrm{H}\right\}$ at $29.84 \mathrm{ppm}, 206.26 \mathrm{ppm}$; dimethyl sulfoxide- $d_{6}:{ }^{1} \mathrm{H}$ at $2.50 \mathrm{ppm}$ and ${ }^{13} \mathrm{C}\left\{{ }^{1} \mathrm{H}\right\}$ at $\left.39.52 \mathrm{ppm}\right)$. Infrared spectra were recorded using a FT-Nicolet IR 200 equipment. The melting points of analytical pure samples (sealed off in nitrogen-purged capillaries) were determined using an Gallenkamp MFB 595010 M melting point apparatus. Microanalyses were performed using a Thermo FLASHEA 1112 Series 
instrument. Spectroelectrochemical measurements were carried out in an OTTLE cell ${ }^{42}$ from dichloromethane solutions containing $0.1 \mathrm{~mol} \cdot \mathrm{L}^{-1}$ of $\left[\mathrm{N}^{n} \mathrm{Bu}_{4}\right]\left[\mathrm{B}\left(\mathrm{C}_{6} \mathrm{~F}_{5}\right)_{4}\right]$ as supporting electrolyte using a Varian Cary 5000 spectrometer. High-resolution mass spectra were performed using a micrOTOF QII Bruker Daltonite workstation.

Electrochemistry. Measurements on $1.0 \mathrm{mmol} \cdot \mathrm{L}^{-1}$ solutions of the analytes in dry air free dichloromethane containing $0.1 \mathrm{~mol} \cdot \mathrm{L}^{-1}$ of $\left[\mathrm{N}^{n} \mathrm{Bu}_{4}\right]\left[\mathrm{B}\left(\mathrm{C}_{6} \mathrm{~F}_{5}\right)_{4}\right]$ as supporting electrolyte were conducted under a blanket of purified argon at $25{ }^{\circ} \mathrm{C}$ utilizing a Radiometer Voltalap PGZ 100 electrochemical workstation interfaced with a personal computer. A three electrode cell, which utilized a Pt auxiliary electrode, a glassy carbon working electrode (surface area $0.031 \mathrm{~cm}^{2}$ ), and an $\mathrm{Ag} / \mathrm{Ag}^{+}\left(0.01 \mathrm{~mol} \cdot \mathrm{L}^{-1}\right.$ $\left.\mathrm{AgNO}_{3}\right)$ reference electrode mounted on a Luggin capillary was used. The working electrode was pretreated by polishing on a Buehler microcloth first with $1 \mu \mathrm{m}$ and then $1 / 4 \mu \mathrm{m}$ diamond paste. The reference electrode was constructed from a silver wire inserted into a solution of $0.01 \mathrm{~mol} \cdot \mathrm{L}^{-1}\left[\mathrm{AgNO}_{3}\right]$ and $0.1 \mathrm{~mol} \cdot \mathrm{L}^{-1}\left[\mathrm{~N}^{n} \mathrm{Bu}_{4}\right]\left[\mathrm{B}\left(\mathrm{C}_{6} \mathrm{~F}_{5}\right)_{4}\right]$ in acetonitrile, in a luggin capillary with a vycor tip. This luggin capillary was inserted into a second luggin capillary with vycor tip filled with a $0.1 \mathrm{~mol} \cdot \mathrm{L}^{-1}$ $\left[\mathrm{N}^{n} \mathrm{Bu}_{4}\right]\left[\mathrm{B}\left(\mathrm{C}_{6} \mathrm{~F}_{5}\right)_{4}\right]$ solution in dichloromethane. ${ }^{32}$ Successive experiments under the same experimental conditions showed that all formal reduction and oxidation potentials were reproducible within $5 \mathrm{mV}$. Experimentally potentials were referenced against an $\mathrm{Ag} / \mathrm{Ag}^{+}$reference electrode but results are presented referenced against ferrocene as an internal standard as required by IUPAC. ${ }^{33}$ When decamethylferrocene was used as an internal standard, the experimentally measured potential was converted into $E \mathrm{vs} \mathrm{FcH} / \mathrm{FcH}^{+}$by addition of $-0.61 \mathrm{~V} .{ }^{51}$ Data were then manipulated on a Microsoft Excel worksheet to set the formal redox potentials of the $\mathrm{FcH} / \mathrm{FcH}^{+}$couple to $E^{\circ \prime}=0.0 \mathrm{~V}$. The cyclic voltammograms, which are depicted, were taken after typical two scans and are considered to be steady state cyclic voltammograms, in which the signal pattern differs not from the initial sweep.

\section{General procedure - Protection with trimethyl silyl group of 2 and 8. The dibromo} (oligo)pyrroles $\mathbf{2}$ or $\mathbf{8}$ were dissolved in $50 \mathrm{~mL}$ of degassed tetrahydrofuran and treated with 1 eq of 
${ }^{n}$ butyllithium at $-80^{\circ} \mathrm{C}$. After $1 \mathrm{~h}$ of stirring at this temperature the color of the solution changed from colorless to pale green (10) or deep purple (11). Then 1.1 eq of trimethyl silyl chloride was added in a single portion and the reaction mixture was slowly allowed to warm to ambient temperature and stirred overnight, whereby the color changed to yellow. After evaporation of all volatiles the crude product was purified by column chromatography (column size: 3 x $25 \mathrm{~cm}$, alumina pretreated with triethyl amine, $n$ hexane as eluent). The $1^{\text {st }}$ fraction contained the appropriate pure product and all volatiles were removed under reduced pressure.

Data for 2-Bromo-5-trimethylsilyl- $N$-phenyl pyrrole (10). 2,5-Dibromo- $N$-phenyl pyrrole (2) $(8.29 \mathrm{~g}, 27.5 \mathrm{mmol}), 1 \mathrm{eq}$ of ${ }^{n}$ butyllithium $(11.0 \mathrm{~mL}, 27.5 \mathrm{mmol})$ and 1.1 eq of trimethyl silyl chloride (3.83 mL, $30.0 \mathrm{mmol})$. Yield: $2.48 \mathrm{~g}$ (8.44 mmol, $31 \%$ based on 2); colorless, air-sensitive solid, soluble in dichloromethane. Anal. calcd for $\mathrm{C}_{13} \mathrm{H}_{16} \mathrm{BrNSi}(294.26 \mathrm{~g} / \mathrm{mol})$ [\%]: C, 53.06; H, 5.48; N,

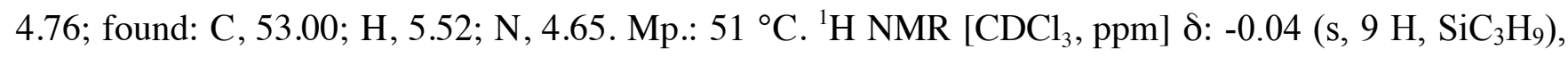
$6.32\left(\mathrm{~d},{ }^{3} J_{\mathrm{H} 4-\mathrm{H} 3}=3.69 \mathrm{~Hz}, 1 \mathrm{H}, \mathrm{H}-4\right), 6.48\left(\mathrm{~d},{ }^{3} J_{\mathrm{H} 3-\mathrm{H} 4}=3.69 \mathrm{~Hz}, 1 \mathrm{H}, \mathrm{H}-3\right), 7.28\left(\mathrm{~m}, 2 \mathrm{H}, \mathrm{C}_{6} \mathrm{H}_{5} / o-\mathrm{H}\right)$, $7.46\left(\mathrm{~m}, 3 \mathrm{H}, \mathrm{C}_{6} \mathrm{H}_{5}\right) .{ }^{13} \mathrm{C}\left\{{ }^{1} \mathrm{H}\right\} \mathrm{NMR}\left[\mathrm{CDCl}_{3}, \mathrm{ppm}\right] \delta:-0.29\left(\mathrm{SiC}_{3} \mathrm{H}_{9}\right), 107.43(\mathrm{C}-2), 111.38(\mathrm{C}-4)$, $120.02(\mathrm{C}-3), 128.77\left(\mathrm{C}_{6} \mathrm{H}_{5}\right), 128.91\left(\mathrm{C}_{6} \mathrm{H}_{5}\right), 129.30\left(\mathrm{C}_{6} \mathrm{H}_{5}\right), 136.85\left(\mathrm{C}_{i}-\mathrm{C}_{6} \mathrm{H}_{5}\right), 140.52\left(\mathrm{C}_{i}-\mathrm{C}-\mathrm{SiC}_{3} \mathrm{H}_{9}\right)$. IR data $\left[\mathrm{KBr}, \mathrm{cm}^{-1}\right]$ v: $750\left(\mathrm{~s}, \delta_{\text {o.o.p. }=\mathrm{C}-\mathrm{H}}\right), 972\left(\mathrm{~s}, \delta_{\mathrm{C}-\mathrm{N}}\right), 1505\left(\mathrm{~s}, v_{\mathrm{C}=\mathrm{C}}\right), 1597\left(\mathrm{~m}, v_{\mathrm{C}=\mathrm{C}}\right), 2895\left(\mathrm{w}, v_{\mathrm{s}-\mathrm{CH} 3}\right)$, $2954\left(\mathrm{w}, \mathrm{v}_{\mathrm{as}-\mathrm{CH} 3}\right), 3098\left(\mathrm{w}, \mathrm{v}_{=\mathrm{C}-\mathrm{H}}\right)$. HR-ESI-MS [m/z]: calcd for $\mathrm{C}_{13} \mathrm{H}_{16} \mathrm{BrNSi}$ : 295.0210, found: 295.0216 $[\mathrm{M}]$.

\section{Data for 5-Bromo-5'-trimethylsilyl- $N, N^{\prime}$-bisphenyl-2,2'-bipyrrole (11). 5,5'-Dibromo- $N, N^{\prime}$ -} bisphenyl-2,2'-bipyrrole (8) (4.98 g, $11.3 \mathrm{mmol}), 1$ eq of ${ }^{n}$ butyllithium (4.53 mL, $\left.11.3 \mathrm{mmol}\right)$ and $1.1 \mathrm{eq}$ of trimethyl silyl chloride (1.57 mL, $12.5 \mathrm{mmol})$. Yield: $4.12 \mathrm{~g}(9.46 \mathrm{mmol}, 84 \%$ based on 8); colorless, air-sensitive solid, soluble in dichloromethane. Anal. calcd for $\mathrm{C}_{23} \mathrm{H}_{23} \mathrm{BrN}_{2} \mathrm{Si}$ (435.43 g/mol) [\%]: C,

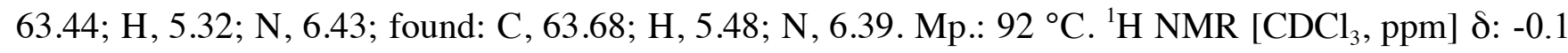


$\left(\mathrm{s}, 9 \mathrm{H}, \mathrm{SiC}_{3} \mathrm{H}_{9}\right), 6.00\left(\mathrm{~d},{ }^{3} J_{\mathrm{H}^{\prime}-\mathrm{H} 3^{\prime}}=3.81 \mathrm{~Hz}, 1 \mathrm{H}, \mathrm{H}-4^{\prime}\right), 6.03\left(\mathrm{~d},{ }^{3} J_{\mathrm{H} 4-\mathrm{H} 3}=3.51 \mathrm{~Hz}, 1 \mathrm{H}, \mathrm{H}-4\right), 6.18(\mathrm{~d}$, $\left.{ }^{3} J_{\mathrm{H}^{\prime}-\mathrm{H} 4^{\prime}}=3.80 \mathrm{~Hz}, 1 \mathrm{H}, \mathrm{H}-3^{\prime}\right), 6.36\left(\mathrm{~d},{ }^{3} J_{\mathrm{H} 3-\mathrm{H} 4}=3.62 \mathrm{~Hz}, 1 \mathrm{H}, \mathrm{H}-3\right), 6.84\left(\mathrm{~m}, 2 \mathrm{H}, \mathrm{C}_{6} \mathrm{H}_{5}{ }^{\prime}\right), 6.89(\mathrm{~m}, 2 \mathrm{H}$, $\left.\mathrm{C}_{6} \mathrm{H}_{5}\right), 7.21-7.36\left(\mathrm{~m}, 6 \mathrm{H}, \mathrm{C}_{6} \mathrm{H}_{5} / \mathrm{C}_{6} \mathrm{H}_{5}{ }^{\prime}\right) .{ }^{13} \mathrm{C}\left\{{ }^{1} \mathrm{H}\right\} \mathrm{NMR}\left[\mathrm{CDCl}_{3}, \mathrm{ppm}\right] \delta:-0.05\left(\mathrm{SiC}_{3} \mathrm{H}_{9}\right), 103.20(\mathrm{C}-5)$, 111.53 (C-3), 112.42 (C-3'), $112.70\left(\mathrm{C}^{\prime} 4^{\prime}\right), 119.19$ (C-4), $124.27\left(\mathrm{C}_{i}-\mathrm{C}-2\right), 127.64\left(\mathrm{C}_{6} \mathrm{H}_{5}\right), 127.78$ $\left(\mathrm{C}_{6} \mathrm{H}_{5}{ }^{\prime}\right), 128.38\left(\mathrm{C}_{6} \mathrm{H}_{5}\right), 128.49\left(\mathrm{C}_{6} \mathrm{H}_{5}{ }^{\prime}\right), 128.51\left(\mathrm{C}_{6} \mathrm{H}_{5}\right), 128.63\left(\mathrm{C}_{6} \mathrm{H}_{5}{ }^{\prime}\right), 130.36\left(\mathrm{C}_{i^{-}} \mathrm{C}^{-}-2^{\prime}\right), 135.60\left(\mathrm{C}_{i^{-}}\right.$ $\left.\mathrm{C}_{6} \mathrm{H}_{5}{ }^{\prime}\right), 138.35\left(\mathrm{C}_{i}-\mathrm{C}_{6} \mathrm{H}_{5}\right), 141.24\left(\mathrm{C}_{i}{ }^{-} \mathrm{C}-\mathrm{SiC}_{3} \mathrm{H}_{9}\right)$. IR data $\left[\mathrm{KBr}, \mathrm{cm}^{-1}\right]$ v: $751\left(\mathrm{~s}, \delta_{\text {o.o.p. }=\mathrm{C}-\mathrm{H}}\right), 967\left(\mathrm{~m}, \delta_{\mathrm{C}-\mathrm{N}}\right)$, $1497\left(\mathrm{~s}, v_{\mathrm{C}=\mathrm{C}}\right), 1595\left(\mathrm{~m}, v_{\mathrm{C}=\mathrm{C}}\right), 2889\left(\mathrm{w}, \mathrm{v}_{\mathrm{s}-\mathrm{CH} 3}\right), 2948\left(\mathrm{w}, \mathrm{v}_{\mathrm{as}-\mathrm{CH} 3}\right), 3100\left(\mathrm{w}, \mathrm{v}_{=\mathrm{C}-\mathrm{H}}\right)$. HR-ESI-MS [m/z]: calcd for $\mathrm{C}_{23} \mathrm{H}_{23} \mathrm{BrN}_{2} \mathrm{Si}: 437.0867$, found: $437.0845[\mathrm{M}]^{+}$.

General procedure - Synthesis of bipyrrole and $\mathrm{Me}_{3} \mathrm{Si}$-protected oligopyrroles. To a solution of the monobromo (oligo)pyrroles $\mathbf{5}$ or $\mathbf{1 1}$ in $50 \mathrm{~mL}$ of degassed tetrahydrofuran was added dropwise via a syringe 1 eq of ${ }^{n}$ butyllithium $\left(2.5 \mathrm{M}\right.$ in $n$-hexane) at $-80^{\circ} \mathrm{C}$. The reaction mixture was stirred for $1 \mathrm{~h}$. Then $\left[\mathrm{ZnCl}_{2} \cdot 2\right.$ thf $](1 \mathrm{eq})$ was added in a single portion to generate in situ $\mathbf{6}$ or $\mathbf{1 2}$. The reaction mixture was stirred for additional $30 \mathrm{~min}$ at $0{ }^{\circ} \mathrm{C}$. Afterward, $0.25 \mathrm{~mol} \%$ of $\left[\mathrm{Pd}\left(\mathrm{CH}_{2} \mathrm{C}\left(\mathrm{CH}_{3}\right)_{2} \mathrm{P}\left({ }^{t} \mathrm{C}_{4} \mathrm{H}_{9}\right)_{2}\right)(\mu-\mathrm{Cl})\right]_{2}$ and 1 eq of 5, 10 or $\mathbf{1 1}$ were added in a single portion and the reaction solutions were stirred overnight at $60{ }^{\circ} \mathrm{C}$. The crude product was worked-up by column chromatography (column size: $3 \mathrm{x} 25 \mathrm{~cm}$, alumina pretreated with triethyl amine). The $1^{\text {st }}$ fraction contained the reactants $\mathbf{5}$ or $\mathbf{1 1}$, while from the $2^{\text {nd }}$ fraction the appropriate pure product could be obtained. All volatiles were removed under reduced pressure.

Data for $N, N^{\prime}$-Bisphenyl-2,2'-bipyrrole (7). 2-Bromo- $N$-phenyl pyrrole (5) (2.95 g, $\left.13.28 \mathrm{mmol}\right), 1$ eq of ${ }^{n}$ butyllithium $(5.4 \mathrm{~mL}, 13.5 \mathrm{mmol}), 1.0$ eq of $\left[\mathrm{ZnCl}_{2} \cdot 2 \mathrm{thf}\right](3.72 \mathrm{~g}, 13.5 \mathrm{mmol}), 1$ eq of 2-bromo-

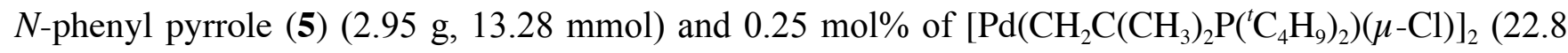
mg). For column chromatography a $n$-hexane/diethyl ether mixture of ratio $6: 1(v / v)$ as eluent was used. Yield: $2.97 \mathrm{~g}$ (10.46 mmol, $77 \%$ based on 5); colorless, fluorescent solid, soluble in dichloromethane. 
Anal. calcd for $\mathrm{C}_{20} \mathrm{H}_{16} \mathrm{~N}_{2}$ (284.35 g/mol) [\%]: C, 84.48; H, 5.67; N, 9.85; found: C, 84.08; H, 5.92; N, 9.90. Mp.: $101{ }^{\circ} \mathrm{C} .{ }^{1} \mathrm{H}$ NMR $\left[\mathrm{CDCl}_{3}, \mathrm{ppm}\right] \delta: 6.32$ (pt, $\left.{ }^{3} J_{\mathrm{H} 4-\mathrm{H} 3}=3.58 \mathrm{~Hz},{ }^{3} J_{\mathrm{H} 4-\mathrm{H} 5}=2.96 \mathrm{~Hz}, 2 \mathrm{H}, \mathrm{H}-4\right)$, $6.44\left(\mathrm{dd},{ }^{4} J_{\mathrm{H} 3-\mathrm{H} 5}=1.84 \mathrm{~Hz},{ }^{3} J_{\mathrm{H} 3-\mathrm{H} 4}=3.54 \mathrm{~Hz}, 2 \mathrm{H}, \mathrm{H}-3\right), 6.57-6.59\left(\mathrm{~m}, 4 \mathrm{H}, \mathrm{C}_{6} \mathrm{H}_{5} / o-\mathrm{H}\right), 6.77\left(\mathrm{dd},{ }^{4} J_{\mathrm{H} 5-\mathrm{H} 3}\right.$ $\left.=1.80 \mathrm{~Hz},{ }^{3} J_{\mathrm{H} 5-\mathrm{H} 4}=2.98 \mathrm{~Hz}, 2 \mathrm{H}, \mathrm{H}-5\right), 7.01-7.05\left(\mathrm{~m}, 6 \mathrm{H}, \mathrm{C}_{6} \mathrm{H}_{5}\right) .{ }^{13} \mathrm{C}\left\{{ }^{1} \mathrm{H}\right\} \mathrm{NMR}\left[\mathrm{CDCl}_{3}, \mathrm{ppm}\right] \delta:$ 109.13 (C-4), 112.59 (C-3), 122.41 (C-5), $123.90\left(\mathrm{C}_{6} \mathrm{H}_{5}\right), 125.18\left(\mathrm{C}_{i}-\mathrm{C}-2\right), 125.57\left(\mathrm{C}_{6} \mathrm{H}_{5}\right), 128.56$ $\left(\mathrm{C}_{6} \mathrm{H}_{5}\right), 140.30\left(\mathrm{C}_{i}-\mathrm{C}_{6} \mathrm{H}_{5}\right)$. IR data $\left[\mathrm{KBr}, \mathrm{cm}^{-1}\right]$ v: $718\left(\mathrm{~s}, \delta_{\text {o.o.p. }=\mathrm{C}-\mathrm{H}}\right), 1072\left(\mathrm{~m}, v_{\mathrm{C}-\mathrm{N}}\right), 1499\left(\mathrm{~s}, v_{\mathrm{C}=\mathrm{C}}\right), 1599$ $\left(\mathrm{m}, v_{\mathrm{C}=\mathrm{C}}\right), 3100\left(\mathrm{w}, v_{=\mathrm{C}-\mathrm{H}}\right)$. HR-ESI-MS [m/z]: calcd for $\mathrm{C}_{20} \mathrm{H}_{16} \mathrm{~N}_{2}: 566.2465$, found: 566.2485 [M] .

\section{Data for 5,5'"-Di-(trimethylsilyl)- $N, N^{\prime}, N^{\prime \prime}$-trisphenyl-2,2':5',2'-terpyrrole (13). 5-Bromo-5'-} trimethylsilyl- $N, N^{\prime}$-bisphenyl-2,2'-bipyrrole (11) $(1.66 \mathrm{~g}, 3.8 \mathrm{mmol}), 1$ eq of ${ }^{n}$ butyllithium $(1.53 \mathrm{~mL}$, $3.8 \mathrm{mmol}), 1.0 \mathrm{eq}$ of $\left[\mathrm{ZnCl}_{2} \cdot 2 \mathrm{thf}\right](1.07 \mathrm{~g}, 3.8 \mathrm{mmol}), 1 \mathrm{eq}$ of 2-bromo-5-trimethylsilyl- $N$-phenyl pyrrole (10) $(1.12 \mathrm{~g}, 3.8 \mathrm{mmol})$ and $0.25 \mathrm{~mol} \%$ of $\left[\mathrm{Pd}\left(\mathrm{CH}_{2} \mathrm{C}\left(\mathrm{CH}_{3}\right)_{2} \mathrm{P}\left({ }^{t} \mathrm{C}_{4} \mathrm{H}_{9}\right)_{2}\right)(\mu-\mathrm{Cl})\right]_{2}(6.53 \mathrm{mg})$. For column chromatography $n$-hexane was used as eluent. Yield: $0.91 \mathrm{~g}$ (1.6 mmol, $42 \%$ based on 11); colorless, fluorescent solid, soluble in dichloromethane. Anal. calcd for $\mathrm{C}_{36} \mathrm{H}_{39} \mathrm{~N}_{2} \mathrm{Si}_{2}(569.89 \mathrm{~g} / \mathrm{mol})$ [\%]:

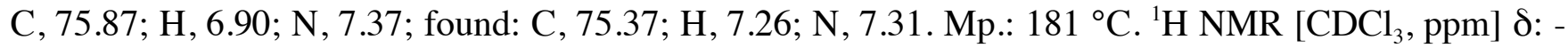
$0.12\left(\mathrm{~s}, 18 \mathrm{H}, \mathrm{SiC}_{3} \mathrm{H}_{9}\right), 6.02\left(\mathrm{~s}, 2 \mathrm{H}, \mathrm{H}-3^{\prime} / 4^{\prime}\right), 6.03\left(\mathrm{~d},{ }^{3} J_{\mathrm{H} 4-\mathrm{H} 3 / \mathrm{H}^{\prime \prime}-\mathrm{H} 3^{\prime \prime}}=3.49 \mathrm{~Hz}, 2 \mathrm{H}, \mathrm{H}-4 / 4^{\prime \prime}\right), 6.28(\mathrm{~m}, 2$ $\left.\mathrm{H}, \mathrm{C}_{6} \mathrm{H}_{5}{ }^{\prime}\right), 6.36\left(\mathrm{~d},{ }^{3} J_{\mathrm{H} 3-\mathrm{H} 4 / \mathrm{H} 3^{\prime \prime}-\mathrm{H} 4^{\prime \prime}}=3.54 \mathrm{~Hz}, 2 \mathrm{H}, \mathrm{H}-3 / 3^{\prime \prime}\right), 6.62\left(\mathrm{~m}, 4 \mathrm{H}, \mathrm{C}_{6} \mathrm{H}_{5} / \mathrm{C}_{6} \mathrm{H}_{5}{ }^{\prime \prime}\right), 6.96(\mathrm{~m}, 2 \mathrm{H}$, $\left.\mathrm{C}_{6} \mathrm{H}_{5}{ }^{\prime}\right), 7.09\left(\mathrm{~m}, 5 \mathrm{H}, \mathrm{C}_{6} \mathrm{H}_{5} / \mathrm{C}_{6} \mathrm{H}_{5}{ }^{\prime} / \mathrm{C}_{6} \mathrm{H}_{5}{ }^{\prime \prime}\right) 7.18\left(\mathrm{~m}, 2 \mathrm{H}, \mathrm{C}_{6} \mathrm{H}_{5} / \mathrm{C}_{6} \mathrm{H}_{5}{ }^{\prime \prime}\right) .{ }^{13} \mathrm{C}\left\{{ }^{1} \mathrm{H}\right\} \mathrm{NMR}\left[\mathrm{CDCl}_{3}, \mathrm{ppm}\right] \delta$ : $0.01\left(\mathrm{SiC}_{3} \mathrm{H}_{9}\right), \quad 112.21\left(\mathrm{C}-3^{\prime} / 4^{\prime}\right), \quad 112.23\left(\mathrm{C}-3 / 3^{\prime \prime}\right), \quad 119.19 \quad\left(\mathrm{C}-4 / 4^{\prime \prime}\right), \quad 125.87 \quad\left(\mathrm{C}_{6} \mathrm{H}_{5}^{\prime}\right), 126.03$ $\left(\mathrm{C}_{6} \mathrm{H}_{5} / \mathrm{C}_{6} \mathrm{H}_{5}{ }^{\prime \prime}\right), 127.03\left(\mathrm{C}_{6} \mathrm{H}_{5}{ }^{\prime}\right), 127.15\left(\mathrm{C}_{6} \mathrm{H}_{5} / \mathrm{C}_{6} \mathrm{H}_{5}{ }^{\prime \prime}\right), 127.95\left(\mathrm{C}_{i^{-}}-\mathrm{C}-2^{\prime} / 5^{\prime}\right), 127.98\left(\mathrm{C}_{6} \mathrm{H}_{5}{ }^{\prime}\right), 128.13$ $\left(\mathrm{C}_{6} \mathrm{H}_{5} / \mathrm{C}_{6} \mathrm{H}_{5}{ }^{\prime \prime}\right), 130.96\left(\mathrm{C}_{i}-\mathrm{C}-2 / 2^{\prime \prime}\right), 135.07\left(\mathrm{C}_{i}-\mathrm{C}_{6} \mathrm{H}_{5} / \mathrm{C}_{i}-\mathrm{C}_{6} \mathrm{H}_{5}{ }^{\prime \prime}\right), 138.87\left(\mathrm{C}_{i^{-}}-\mathrm{C}_{6} \mathrm{H}_{5}{ }^{\prime}\right), 141.24\left(\mathrm{C}_{i}-\mathrm{C}-\right.$ $\left.\mathrm{SiC}_{3} \mathrm{H}_{9} / \mathrm{C}-\mathrm{SiC}_{3} \mathrm{H}_{9}{ }^{\prime \prime}\right)$. IR data $\left[\mathrm{KBr}, \mathrm{cm}^{-1}\right]$ v: $756\left(\mathrm{~s}, \delta_{\text {o.o.p. }=\mathrm{C}-\mathrm{H}}\right), 1496\left(\mathrm{~s}, v_{\mathrm{C}=\mathrm{C}}\right), 1595\left(\mathrm{~m}, v_{\mathrm{C}=\mathrm{C}}\right), 2899$ (w, $\left.v_{\mathrm{s}-\mathrm{CH} 3}\right), 2952\left(\mathrm{w}, \mathrm{v}_{\mathrm{as}-\mathrm{CH} 3}\right), 3091\left(\mathrm{w}, \mathrm{v}_{=\mathrm{C}-\mathrm{H}}\right)$. HR-ESI-MS [m/z]: calcd for $\mathrm{C}_{36} \mathrm{H}_{39} \mathrm{~N}_{3} \mathrm{Si}_{2}: 570.2755$, found: $570.2701[\mathrm{M}]^{+}$. 


\section{Data for $5,5^{\prime \prime \prime}$-Di-(trimethylsilyl)- $N, N^{\prime}, N^{\prime \prime}, N^{\prime \prime \prime}$-tetrakisphenyl-2,2':5',2"':5", $2^{\prime \prime \prime}$-quarter-}

pyrrole (17). 5-Bromo-5'-trimethylsilyl- $N, N^{\prime}$-bisphenyl-2,2’'bipyrrole (11) (1.07 g, $\left.2.47 \mathrm{mmol}\right), 1 \mathrm{eq}$ of ${ }^{n}$ butyllithium $(1.0 \mathrm{~mL}, 2.47 \mathrm{mmol}), 1.0$ eq of $\left[\mathrm{ZnCl}_{2} \cdot 2 \mathrm{thf}\right](0.69 \mathrm{~g}, 2.47 \mathrm{mmol}), 1$ eq of 11 (1.07 g, $2.47 \mathrm{mmol})$ and $0.25 \mathrm{~mol} \%$ of $\left[\mathrm{Pd}\left(\mathrm{CH}_{2} \mathrm{C}\left(\mathrm{CH}_{3}\right)_{2} \mathrm{P}\left({ }^{t} \mathrm{C}_{4} \mathrm{H}_{9}\right)_{2}\right)(\mu-\mathrm{Cl})\right]_{2} \quad(4.23 \mathrm{mg})$. For column chromatography a $n$-hexane/diethyl ether mixture of ratio 10:1 $(v / v)$ was used as eluent. Yield: $0.99 \mathrm{~g}$ (1.4 mmol, $57 \%$ based on 11); colorless, fluorescent solid, soluble in dichloromethane. Anal. calcd for $\mathrm{C}_{36} \mathrm{H}_{39} \mathrm{~N}_{2} \mathrm{Si}_{2}(711.06 \mathrm{~g} / \mathrm{mol})$ [\%]: C, 77.70; H, 6.52; N, 7.88; found: C, 77.37; H, 6.70; N, 7.88. Mp.: 211 ${ }^{\circ} \mathrm{C} .{ }^{1} \mathrm{H} \mathrm{NMR}\left[\mathrm{CDCl}_{3}, \mathrm{ppm}\right] \delta:-0.13\left(\mathrm{~s}, 18 \mathrm{H}, \mathrm{SiC}_{3} \mathrm{H}_{9}\right), 5.93\left(\mathrm{~d},{ }^{3} J_{\mathrm{H} 4-\mathrm{H} 3 / \mathrm{H} 4^{\prime \prime \prime}-\mathrm{H} 3^{\prime \prime}}=3.64 \mathrm{~Hz}, 2 \mathrm{H}, \mathrm{H}-4 / 4^{\prime \prime \prime}\right)$, $6.02\left(\mathrm{~d},{ }^{3} J_{\mathrm{H} 3-\mathrm{H} 4 / \mathrm{H}^{\prime \prime \prime}-\mathrm{H} 4^{\prime \prime \prime}}=3.64 \mathrm{~Hz}, 2 \mathrm{H}, \mathrm{H}-3 / 3^{\prime \prime \prime}\right), 6.04\left(\mathrm{~d},{ }^{3} \mathrm{~J}_{\mathrm{H}^{\prime}-\mathrm{H} 4^{\prime} / \mathrm{H}^{\prime \prime \prime}-\mathrm{H} 3^{\prime \prime}}=3.50 \mathrm{~Hz}, 2 \mathrm{H}, \mathrm{H}-3^{\prime} / 4^{\prime \prime}\right), 6.07$ $\left(\mathrm{m}, 4 \mathrm{H}, \mathrm{C}_{6} \mathrm{H}_{5} / \mathrm{C}_{6} \mathrm{H}_{5}{ }^{\prime \prime \prime}\right), 6.36\left(\mathrm{~d},{ }^{3} J_{\mathrm{H}^{\prime}-\mathrm{H} 3^{\prime} / \mathrm{H}^{\prime \prime}-\mathrm{H} 4^{\prime \prime}}=3.50 \mathrm{~Hz}, 2 \mathrm{H}, \mathrm{H}-4^{\prime} / 3^{\prime \prime}\right), 6.58\left(\mathrm{~m}, 4 \mathrm{H}, \mathrm{C}_{6} \mathrm{H}_{5}{ }^{\prime} / \mathrm{C}_{6} \mathrm{H}_{5}{ }^{\prime \prime}\right)$, $6.84\left(\mathrm{~m}, 4 \mathrm{H}, \mathrm{C}_{6} \mathrm{H}_{5} / \mathrm{C}_{6} \mathrm{H}_{5}{ }^{\prime \prime \prime}\right), 6.98\left(\mathrm{~m}, 2 \mathrm{H}, \mathrm{C}_{6} \mathrm{H}_{5} / \mathrm{C}_{6} \mathrm{H}_{5}{ }^{\prime \prime \prime}\right), 7.08$ (m, $\left.4 \mathrm{H}, \mathrm{C}_{6} \mathrm{H}_{5}{ }^{\prime} / \mathrm{C}_{6} \mathrm{H}_{5}{ }^{\prime \prime}\right), 7.18(\mathrm{~m}, 2 \mathrm{H}$, $\left.\mathrm{C}_{6} \mathrm{H}_{5}{ }^{\prime} / \mathrm{C}_{6} \mathrm{H}_{5}{ }^{\prime \prime}\right) .{ }^{13} \mathrm{C}\left\{{ }^{1} \mathrm{H}\right\}$ NMR $\left[\mathrm{CDCl}_{3}, \mathrm{ppm}\right] \delta:-0.03\left(\mathrm{SiC}_{3} \mathrm{H}_{9}\right), 111.98\left(\mathrm{C}-3^{\prime} / 4^{\prime \prime}\right), 112.13\left(\mathrm{C}-4^{\prime} / 3^{\prime \prime}\right)$, $112.26\left(\mathrm{C}-3 / 3^{\prime \prime \prime}\right), 119.16\left(\mathrm{C}-4 / 4^{\prime \prime \prime}\right), 125.53\left(\mathrm{C}_{6} \mathrm{H}_{5} / \mathrm{C}_{6} \mathrm{H}_{5}{ }^{\prime \prime \prime}\right), 125.92\left(\mathrm{C}_{i}-\mathrm{C}-2^{\prime} / 5^{\prime \prime}\right), 126.11\left(\mathrm{C}_{i}-\mathrm{C}-5^{\prime} / 2^{\prime \prime}\right)$, $126.75\left(\mathrm{C}_{6} \mathrm{H}_{5} / \mathrm{C}_{6} \mathrm{H}_{5}{ }^{\prime \prime \prime}\right), 127.01\left(\mathrm{C}_{6} \mathrm{H}_{5}{ }^{\prime} / \mathrm{C}_{6} \mathrm{H}_{5}{ }^{\prime \prime}\right), 127.68\left(\mathrm{C}_{6} \mathrm{H}_{5}{ }^{\prime} / \mathrm{C}_{6} \mathrm{H}_{5}{ }^{\prime \prime}\right), 127.99\left(\mathrm{C}_{6} \mathrm{H}_{5} / \mathrm{C}_{6} \mathrm{H}_{5}{ }^{\prime \prime \prime}\right), 128.05$ $\left(\mathrm{C}_{6} \mathrm{H}_{5}{ }^{\prime} / \mathrm{C}_{6} \mathrm{H}_{5}{ }^{\prime \prime}\right), 130.94\left(\mathrm{C}_{i}-\mathrm{C}-2 / 2^{\prime \prime \prime}\right), 135.11\left(\mathrm{C}_{i}-\mathrm{C}_{6} \mathrm{H}_{5} / \mathrm{C}_{i}-\mathrm{C}_{6} \mathrm{H}_{5}{ }^{\prime \prime \prime}\right), 138.52\left(\mathrm{C}_{i}-\mathrm{C}_{6} \mathrm{H}_{5}{ }^{\prime} / \mathrm{C}_{6} \mathrm{H}_{5}{ }^{\prime \prime}\right), 141.20$ $\left(\mathrm{C}_{i}-\mathrm{C}-\mathrm{SiC}_{3} \mathrm{H}_{9} / \mathrm{C}-\mathrm{SiC}_{3} \mathrm{H}_{9}{ }^{\prime \prime \prime}\right) . \mathrm{IR}$ data $\left[\mathrm{KBr}, \mathrm{cm}^{-1}\right]$ v: $756\left(\mathrm{~s}, \delta_{\text {o.o.p. }=\mathrm{C}-\mathrm{H}}\right), 1497\left(\mathrm{~s}, v_{\mathrm{C}=\mathrm{C}}\right), 1596\left(\mathrm{~m}, v_{\mathrm{C}=\mathrm{C}}\right)$, $2893\left(\mathrm{w}, \mathrm{v}_{\mathrm{s}-\mathrm{CH} 3}\right), 2952\left(\mathrm{w}, \mathrm{v}_{\text {as-CH} 3}\right), 3097\left(\mathrm{w}, \mathrm{v}_{\mathrm{=C}-\mathrm{H}}\right)$. HR-ESI-MS [m/z]: calcd for $\mathrm{C}_{46} \mathrm{H}_{46} \mathrm{~N}_{4} \mathrm{Si}_{2}: 710.3275$, found: $710.3256[\mathrm{M}]$.

\section{General procedure - Deprotection of the oligopyrroles 13 and 17. The $\mathrm{Me}_{3} \mathrm{Si}$-protected}

oligopyrroles 13 and 17, respectively, were dissolved in $20 \mathrm{~mL}$ of degassed tetrahydrofuran and 3 eq of tetra- $n$-butylammonium fluoride were added in a single portion at $-40{ }^{\circ} \mathrm{C}$. The reaction mixture was slowly warmed to ambient temperature and stirred for $2 \mathrm{~d}$, whereby the colorless solution changed to pale blue. After evaporation of all volatiles the crude product was worked-up by filtration (column size: $1.5 \times 10 \mathrm{~cm}$, alumina pretreated with triethyl amine). For column chromatography a $n$-hexane/diethyl 
ether mixture of ratio 10:1 (v/v) was used as eluent. The $1^{\text {st }}$ fraction contained reactant $\mathbf{1 3}$ or $\mathbf{1 7}$, while from the $2^{\text {nd }}$ fraction the appropriate pure product could be isolated. All volatiles were removed under reduced pressure.

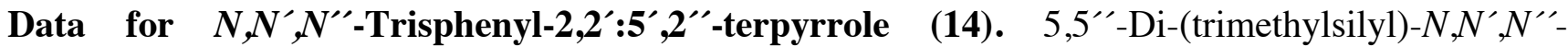

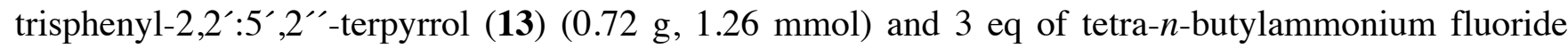
(1.19 g, $3.78 \mathrm{mmol})$. Yield: $0.51 \mathrm{~g}$ (1.19 mmol, $95 \%$ based on 13); colorless, fluorescent solid, soluble in dichloromethane. Anal. calcd for $\mathrm{C}_{30} \mathrm{H}_{23} \mathrm{~N}_{3}$ (425.52 g/mol) [\%]: C, 84.68; H, 5.45; N, 9.87; found: C,

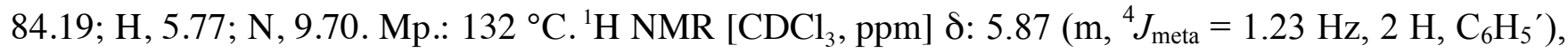

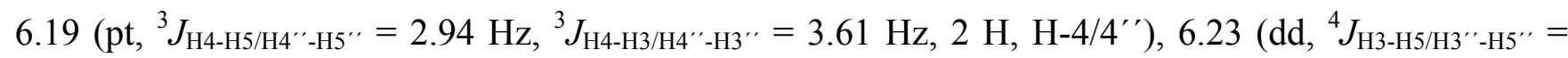
$\left.1.82 \mathrm{~Hz},{ }^{3} J_{\mathrm{H} 3-\mathrm{H} 4 / \mathrm{H}_{3}{ }^{\prime \prime}-\mathrm{H} 4^{\prime \prime}}=3.60 \mathrm{~Hz}, 2 \mathrm{H}, \mathrm{H}-3 / 3^{\prime \prime}\right), 6.36\left(\mathrm{~s}, 2 \mathrm{H}, \mathrm{H}-3^{\prime} / 4^{\prime}\right), 6.61$ (m, $\left.4 \mathrm{H}, \mathrm{C}_{6} \mathrm{H}_{5} / \mathrm{C}_{6} \mathrm{H}_{5}{ }^{\prime \prime}\right)$, $6.65\left(\mathrm{~m}, 2 \mathrm{H}, \mathrm{C}_{6} \mathrm{H}_{5} / \mathrm{C}_{6} \mathrm{H}_{5}{ }^{\prime \prime}\right), 6.67\left(\mathrm{dd},{ }^{4} J_{\mathrm{H} 5-\mathrm{H} 3 / \mathrm{H} 55^{\prime \prime}-\mathrm{H} 3^{\prime \prime}}=1.82 \mathrm{~Hz},{ }^{3} J_{\mathrm{H} 5-\mathrm{H} 4 / \mathrm{H} 5^{\prime \prime}-\mathrm{H} 4^{\prime \prime}}=2.92 \mathrm{~Hz}, 2 \mathrm{H}, \mathrm{H}-5 / 5^{\prime \prime}\right)$, $6.82\left(\mathrm{tt},{ }^{4} J_{\text {meta }}=1.21 \mathrm{~Hz}, 1 \mathrm{H}, \mathrm{C}_{6} \mathrm{H}_{5}{ }^{\prime}\right), 7.04\left(\mathrm{~m}, 6 \mathrm{H}, \mathrm{C}_{6} \mathrm{H}_{5} / \mathrm{C}_{6} \mathrm{H}_{5}{ }^{\prime} / \mathrm{C}_{6} \mathrm{H}_{5}{ }^{\prime \prime}\right) .{ }^{13} \mathrm{C}\left\{{ }^{1} \mathrm{H}\right\} \mathrm{NMR}\left[\mathrm{CDCl}_{3}, \mathrm{ppm}\right]$

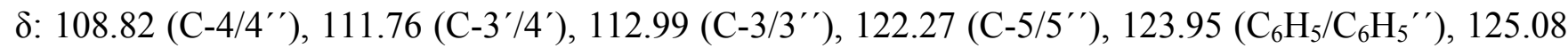
$\left(\mathrm{C}_{6} \mathrm{H}_{5}{ }^{\prime}\right), 125.23\left(\mathrm{C}_{6} \mathrm{H}_{5}{ }^{\prime}\right), 125.65\left(\mathrm{C}_{6} \mathrm{H}_{5} / \mathrm{C}_{6} \mathrm{H}_{5}{ }^{\prime \prime}\right), 126.05\left(\mathrm{C}_{i}-\mathrm{C}-2 / 2^{\prime \prime}\right), 126.31\left(\mathrm{C}_{6} \mathrm{H}_{5}{ }^{\prime}\right), 127.50\left(\mathrm{C}_{i}-\mathrm{C}-\right.$ $\left.2^{\prime} / 5^{\prime}\right), 128.56\left(\mathrm{C}_{6} \mathrm{H}_{5} / \mathrm{C}_{6} \mathrm{H}_{5}{ }^{\prime \prime}\right), 138.29\left(\mathrm{C}_{i^{-}}-\mathrm{C}_{6} \mathrm{H}_{5}{ }^{\prime}\right), 140.33\left(\mathrm{C}_{i}-\mathrm{C}_{6} \mathrm{H}_{5} / \mathrm{C}_{i}-\mathrm{C}_{6} \mathrm{H}_{5}{ }^{\prime \prime}\right) . \mathrm{IR}$ data $\left[\mathrm{KBr}, \mathrm{cm}^{-1}\right]$ v: 757 $\left(\mathrm{s}, \delta_{\text {o.o.p. }=\mathrm{C}-\mathrm{H}}\right), 1499\left(\mathrm{~s}, \mathrm{v}_{\mathrm{C}=\mathrm{C}}\right), 1599\left(\mathrm{~m}, \mathrm{v}_{\mathrm{C}=\mathrm{C}}\right), 3055\left(\mathrm{w}, \mathrm{v}_{=\mathrm{C}-\mathrm{H}}\right)$. HR-ESI-MS [m/z]: calcd for $\mathrm{C}_{30} \mathrm{H}_{23} \mathrm{~N}_{3}$ : 426.1965, found: $426.1962[\mathrm{M}]^{+}$.

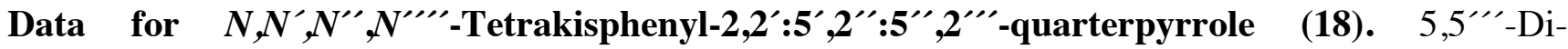

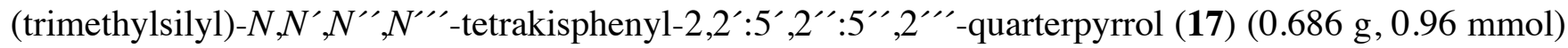
and 3 eq of tetra- $n$-butylammonium fluoride $(0.913 \mathrm{~g}, 2.88 \mathrm{mmol})$. Yield: $0.545 \mathrm{~g}(0.96 \mathrm{mmol}, 100 \%$ based on 17); colorless fluorescent solid, soluble in dichloromethane. Anal. calcd for $\mathrm{C}_{40} \mathrm{H}_{30} \mathrm{~N}_{4}(566.69$ g/mol) [\%]: C, 84.78; H, 5.34; N, 9.80; found: C, 84.60; H, 5.37; N, 9.80. Mp.: $177{ }^{\circ} \mathrm{C} .{ }^{1} \mathrm{H}$ NMR

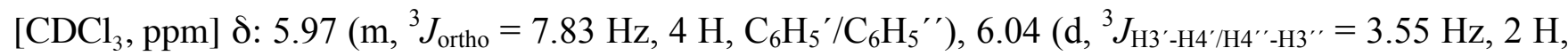


$\left.\mathrm{H}-3^{\prime} / 4^{\prime \prime}\right), 6.18\left(\mathrm{~m},{ }^{3} J_{\mathrm{H} 4-\mathrm{H} 5 / \mathrm{H}^{\prime \prime \prime}-\mathrm{H} 5^{\prime \prime \prime}}=3.25 \mathrm{~Hz}, 2 \mathrm{H}, \mathrm{H}-4 / 4^{\prime \prime \prime}\right), 6.21\left(\mathrm{~m},{ }^{3} J_{\mathrm{H} 5-\mathrm{H} 4 / \mathrm{H} 5^{\prime \prime \prime}-\mathrm{H} 4^{\prime \prime \prime}}=3.25 \mathrm{~Hz},{ }^{4} J_{\mathrm{H} 5-}\right.$ $\left.\mathrm{H} 3 / \mathrm{H}^{\prime \prime \prime-}-\mathrm{H} 3^{\prime \prime \prime}=1.80 \mathrm{~Hz}, 2 \mathrm{H}, \mathrm{H}-5 / 5^{\prime \prime \prime}\right), 6.23\left(\mathrm{~d},{ }^{3} \mathrm{~J}_{\mathrm{H} 4^{\prime}-\mathrm{H} 3^{\prime} / \mathrm{H}^{\prime \prime}-\mathrm{H} 4^{\prime \prime}}=3.59 \mathrm{~Hz}, 2 \mathrm{H}, \mathrm{H}-4^{\prime} / 3^{\prime \prime}\right), 6.56\left(\mathrm{~m},{ }^{3} \mathrm{~J}_{\text {ortho }}=\right.$ $\left.7.83 \mathrm{~Hz}, 4 \mathrm{H}, \mathrm{C}_{6} \mathrm{H}_{5} / \mathrm{C}_{6} \mathrm{H}_{5}{ }^{\prime \prime \prime}\right), 6.65\left(\mathrm{~m},{ }^{4} J_{\mathrm{H} 3-\mathrm{H} 5 / \mathrm{H} 3{ }^{\prime \prime \prime}-\mathrm{H} 5^{\prime \prime \prime}}=1.82 \mathrm{~Hz}, 2 \mathrm{H}, \mathrm{H}-3 / 3^{\prime \prime \prime}\right), 6.73$ (m, ${ }^{3} J_{\text {ortho }}=7.83$ $\left.\mathrm{Hz}, 4 \mathrm{H}, \mathrm{C}_{6} \mathrm{H}_{5}{ }^{\prime} / \mathrm{C}_{6} \mathrm{H}_{5}{ }^{\prime \prime}\right), 6.88$ (m, $\left.2 \mathrm{H}, \mathrm{C}_{6} \mathrm{H}_{5}{ }^{\prime} / \mathrm{C}_{6} \mathrm{H}_{5}{ }^{\prime \prime}\right), 7.03$ (m, ${ }^{3} J_{\text {ortho }}=7.83 \mathrm{~Hz}, 4 \mathrm{H}, \mathrm{C}_{6} \mathrm{H}_{5} / \mathrm{C}_{6} \mathrm{H}_{5}{ }^{\prime \prime \prime}$ ), $7.08\left(\mathrm{~m}, 2 \mathrm{H}, \mathrm{C}_{6} \mathrm{H}_{5} / \mathrm{C}_{6} \mathrm{H}_{5}{ }^{\prime \prime \prime}\right) .{ }^{13} \mathrm{C}\left\{{ }^{1} \mathrm{H}\right\}$ NMR $\left[\mathrm{CDCl}_{3}, \mathrm{ppm}\right] \delta: 108.83\left(\mathrm{C}-4 / 4^{\prime \prime \prime}\right), 111.51\left(\mathrm{C}-3 / 3^{\prime \prime \prime}\right)$, $112.14\left(\mathrm{C}-3^{\prime} / 4^{\prime \prime}\right), 112.92\left(\mathrm{C}-4 / 3^{\prime \prime}\right), 122.70\left(\mathrm{C}-5 / 5^{\prime \prime \prime}\right), 123.90\left(\mathrm{C}_{6} \mathrm{H}_{5} / \mathrm{C}_{6} \mathrm{H}_{5}{ }^{\prime \prime \prime}\right), 125.24\left(\mathrm{C}_{i}-2 / 2^{\prime \prime}\right), 125.28$ $\left(\mathrm{C}_{6} \mathrm{H}_{5} / \mathrm{C}_{6} \mathrm{H}_{5}{ }^{\prime \prime \prime}\right), \quad 125.54 \quad\left(\mathrm{C}_{6} \mathrm{H}_{5}{ }^{\prime} / \mathrm{C}_{6} \mathrm{H}_{5}{ }^{\prime \prime}\right), \quad 126.02 \quad\left(\mathrm{C}_{i}-\mathrm{C}-5^{\prime \prime} / 2^{\prime \prime \prime}\right), \quad 126.31 \quad\left(\mathrm{C}_{i}-\mathrm{C}-5^{\prime} / 2^{\prime \prime}\right), \quad 126.35$ $\left(\mathrm{C}_{6} \mathrm{H}_{5}{ }^{\prime} / \mathrm{C}_{6} \mathrm{H}_{5}{ }^{\prime \prime}\right), 127.50\left(\mathrm{C}_{6} \mathrm{H}_{5}{ }^{\prime} / \mathrm{C}_{6} \mathrm{H}_{5}{ }^{\prime \prime}\right), 128.52\left(\mathrm{C}_{6} \mathrm{H}_{5} / \mathrm{C}_{6} \mathrm{H}_{5}{ }^{\prime \prime \prime}\right), 138.25\left(\mathrm{C}_{i}-\mathrm{C}_{6} \mathrm{H}_{5}{ }^{\prime} / \mathrm{C}_{i}-\mathrm{C}_{6} \mathrm{H}_{5}{ }^{\prime \prime}\right), 140.34$ $\left(\mathrm{C}_{i}-\mathrm{C}_{6} \mathrm{H}_{5} / \mathrm{C}_{i}-\mathrm{C}_{6} \mathrm{H}_{5}{ }^{\prime \prime \prime}\right)$. IR data $\left[\mathrm{KBr}, \mathrm{cm}^{-1}\right]$ v: $769\left(\mathrm{~s}, \delta_{\text {o.o.p. }=\mathrm{C}-\mathrm{H}}\right), 1500\left(\mathrm{~s}, v_{\mathrm{C}=\mathrm{C}}\right), 1597\left(\mathrm{~m}, v_{\mathrm{C}=\mathrm{C}}\right), 3100(\mathrm{w}$, $\left.v_{=\mathrm{C}-\mathrm{H}}\right)$. HR-ESI-MS [m/z]: calcd for $\mathrm{C}_{40} \mathrm{H}_{30} \mathrm{~N}_{4}: 566.2453$, found: $426.2465[\mathrm{M}]$.

General procedure - Synthesis of dibromo oligopyrroles 7, 14 and 18. According to a modified procedure from Gilow et al..$^{25}$ unsubstituted $N$-phenyl (oligo)pyrrole 7, 14 and 18 were dissolved in 30 $\mathrm{mL}$ of degassed tetrahydrofuran and 2 eq of $N$-bromosuccinimide were added in a single portion at -78 ${ }^{\circ} \mathrm{C}$. After 30 min of stirring at this temperature the solution was slowly warmed to ambient temperature and stirred for additional $2 \mathrm{~h}$. Then the pink (7) or purple (14 and $\mathbf{1 8})$ reaction mixture was extracted three times with $20 \mathrm{~mL}$ of diethyl ether. The organic phase was washed three times with an aqueous $\mathrm{Na}_{2} \mathrm{CO}_{3}$ solution and dried over $\mathrm{MgSO}_{4}$. The solvent was evaporated to dryness in oil-pump vacuum yielding a colorless precipitate.. The crude product was washed twice with cold $n$-pentane $\left(0{ }^{\circ} \mathrm{C}\right)$ and finally dried in oil-pump vacuum.

Data for 5,5'-dibromo- $N, N^{\prime}$-bisphenyl-2,2'-bipyrrole (8). $N, N^{\prime}$-Bisphenyl-2,2'-bipyrrol (3) (2.36 g, $8.31 \mathrm{mmol})$ and 2 eq of $N$-bromosuccinimide (2.96 g, $16.62 \mathrm{mmol})$. Yield: $2.88 \mathrm{~g}(6.54 \mathrm{mmol}, 79 \%$ based on 3); colorless solid, soluble in dichloromethane. Anal. calcd for $\mathrm{C}_{20} \mathrm{H}_{14} \mathrm{~N}_{2} \mathrm{Br}_{2}(442.15 \mathrm{~g} / \mathrm{mol})$ [\%]: C, 54.33; H, 3.19; N, 6.34; found: C, 54.39; H, 3.36; N, 6.28. Mp.: $168.5{ }^{\circ} \mathrm{C} .{ }^{1} \mathrm{H}$ NMR $\left[\mathrm{CDCl}_{3}\right.$, 
ppm] $\delta: 6.05\left(\mathrm{~d},{ }^{3} \mathrm{JH}_{3}-\mathrm{H}_{4}=3.80 \mathrm{~Hz}, 2 \mathrm{H}, \mathrm{H}-3\right), 6.19\left(\mathrm{~d},{ }^{3} \mathrm{JH}_{4}-\mathrm{H}_{3}=3.80 \mathrm{~Hz}, 2 \mathrm{H}, \mathrm{H}-4\right), 6.79(\mathrm{~m}, 4 \mathrm{H}$, $\left.\mathrm{C}_{6} \mathrm{H}_{5}\right), 7.22-7.27\left(\mathrm{~m}, 6 \mathrm{H}, \mathrm{C}_{6} \mathrm{H}_{5}\right) .{ }^{13} \mathrm{C}\left\{{ }^{1} \mathrm{H}\right\} \mathrm{NMR}\left[\mathrm{CDCl}_{3}, \mathrm{ppm}\right] \delta: 103.56(\mathrm{C}-5), 111.56(\mathrm{C}-3), 113.19$ (C-4), $127.13\left(\mathrm{C}_{i}-\mathrm{C}-2\right), 127.84\left(\mathrm{C}_{6} \mathrm{H}_{5}\right), 128.38\left(\mathrm{C}_{6} \mathrm{H}_{5}\right), 128.55\left(\mathrm{C}_{6} \mathrm{H}_{5}\right), 137.90\left(\mathrm{C}_{i}-\mathrm{C}_{6} \mathrm{H}_{5}\right)$. IR data [KBr, $\left.\mathrm{cm}^{-1}\right]$ v: 755, $764\left(\mathrm{~s}, \delta_{\text {o.o.p. }=\mathrm{C}-\mathrm{H}}\right), 1070\left(\mathrm{~m}, v_{\mathrm{C}-\mathrm{N}}\right), 1496\left(\mathrm{~s}, v_{\mathrm{C}=\mathrm{C}}\right), 1595\left(\mathrm{~m}, v_{\mathrm{C}=\mathrm{C}}\right), 3032\left(\mathrm{w}, v_{=\mathrm{C}-\mathrm{H}}\right)$. HR-ESIMS [m/z]: calcd for $\mathrm{C}_{20} \mathrm{H}_{14} \mathrm{~N}_{2} \mathrm{Br}_{2}$ : 441.9499, found: 441.9499 [M].

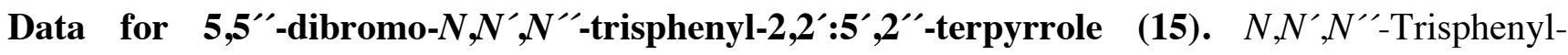
2,2':5',2"'-terpyrrol (14) (0.43 g, $1.0 \mathrm{mmol})$ and 2 eq of $N$-bromosuccinimide (0.36 g, $2.0 \mathrm{mmol})$. Yield: $0.49 \mathrm{~g}$ (0.84 mmol, $84 \%$ based on 14); colorless solid, soluble in dichloromethane. Anal. calcd for $\mathrm{C}_{30} \mathrm{H}_{21} \mathrm{~N}_{3} \mathrm{Br}_{2}(583.32 \mathrm{~g} / \mathrm{mol})[\%]: \mathrm{C}, 61.77 ; \mathrm{H}, 3.63 ; \mathrm{N}, 7.20$; found: C, 61.55; H, 3.74; N, 6.89. Mp.: 181 ${ }^{\circ} \mathrm{C} .{ }^{1} \mathrm{H}$ NMR $\left[\left(\mathrm{CD}_{3}\right)_{2} \mathrm{CO}, \mathrm{ppm}\right] \delta: 5.94\left(\mathrm{~d},{ }^{3} J_{\mathrm{H} 3-\mathrm{H} 4 / \mathrm{H} 3^{\prime \prime}-\mathrm{H} 4^{\prime \prime}}=3.84 \mathrm{~Hz}, 2 \mathrm{H}, \mathrm{H}-3 / 3^{\prime \prime}\right), 5.96$ (s, $\left.2 \mathrm{H}, \mathrm{H}-3^{\prime} / 4^{\prime}\right)$, $6.17\left(\mathrm{~d},{ }^{3} J_{\mathrm{H} 4-\mathrm{H} 3 / \mathrm{H}_{4}{ }^{\prime \prime}-\mathrm{H} 3^{\prime \prime}}=3.84 \mathrm{~Hz}, 2 \mathrm{H}, \mathrm{H}-4 / 4^{\prime \prime}\right), 6.40\left(\mathrm{~m}, 2 \mathrm{H}, \mathrm{C}_{6} \mathrm{H}_{5}{ }^{\prime}\right), 6.72\left(\mathrm{~m}, 4 \mathrm{H}, \mathrm{C}_{6} \mathrm{H}_{5} / \mathrm{C}_{6} \mathrm{H}_{5}{ }^{\prime \prime}\right), 7.09$ (m, $\left.2 \mathrm{H}, \mathrm{C}_{6} \mathrm{H}_{5}{ }^{\prime}\right), 7.19\left(\mathrm{~m}, 1 \mathrm{H}, \mathrm{C}_{6} \mathrm{H}_{5}{ }^{\prime}\right), 7.27$ (m, $\left.4 \mathrm{H}, \mathrm{C}_{6} \mathrm{H}_{5} / \mathrm{C}_{6} \mathrm{H}_{5}{ }^{\prime \prime}\right), 7.34\left(\mathrm{~m}, 2 \mathrm{H}, \mathrm{C}_{6} \mathrm{H}_{5} / \mathrm{C}_{6} \mathrm{H}_{5}{ }^{\prime \prime}\right)$. ${ }^{13} \mathrm{C}\left\{{ }^{1} \mathrm{H}\right\} \mathrm{NMR}\left[\left(\mathrm{CD}_{3}\right)_{2} \mathrm{CO}, \mathrm{ppm}\right] \delta: 103.24\left(\mathrm{C}-5 / 5^{\prime \prime}\right), 112.19\left(\mathrm{C}-3^{\prime} / 4^{\prime}\right), 113.34\left(\mathrm{C}-3 / 3^{\prime \prime}\right), 113.53(\mathrm{C}-$ 4/4' $), 126.63\left(\mathrm{C}_{i}-\mathrm{C}-2 / 2^{\prime \prime}\right), 127.45\left(\mathrm{C}_{6} \mathrm{H}_{5}{ }^{\prime}\right), 128.14\left(\mathrm{C}_{6} \mathrm{H}_{5} / \mathrm{C}_{6} \mathrm{H}_{5}{ }^{\prime \prime}\right), 128.44\left(\mathrm{C}_{6} \mathrm{H}_{5}{ }^{\prime}\right), 128.60\left(\mathrm{C}_{6} \mathrm{H}_{5}{ }^{\prime}\right)$, $129.01\left(\mathrm{C}_{i}-\mathrm{C}-2^{\prime} / 5^{\prime}\right), 129.03\left(\mathrm{C}_{6} \mathrm{H}_{5} / \mathrm{C}_{6} \mathrm{H}_{5}{ }^{\prime \prime}\right), 129.25\left(\mathrm{C}_{6} \mathrm{H}_{5} / \mathrm{C}_{6} \mathrm{H}_{5}{ }^{\prime \prime}\right), 138.69\left(\mathrm{C}_{i}-\mathrm{C}_{6} \mathrm{H}_{5} / \mathrm{C}_{i}-\mathrm{C}_{6} \mathrm{H}_{5}{ }^{\prime \prime}\right), 139.02$ $\left(\mathrm{C}_{i}-\mathrm{C}_{6} \mathrm{H}_{5}{ }^{\prime}\right) . \mathrm{IR}$ data $\left[\mathrm{KBr}, \mathrm{cm}^{-1}\right]$ v: $757\left(\mathrm{~s}, \delta_{\text {o.o.p. }}=\mathrm{C}-\mathrm{H}\right), 1497\left(\mathrm{~s}, v_{\mathrm{C}=\mathrm{C}}\right), 1596\left(\mathrm{~m}, v_{\mathrm{C}=\mathrm{C}}\right), 3059\left(\mathrm{w}, v_{=\mathrm{C}-\mathrm{H}}\right)$. HR-ESI-MS [m/z]: calcd for $\mathrm{C}_{30} \mathrm{H}_{21} \mathrm{~N}_{3} \mathrm{Br}_{2}: 584.0157$, found: 584.0087 [M] $]^{+}$

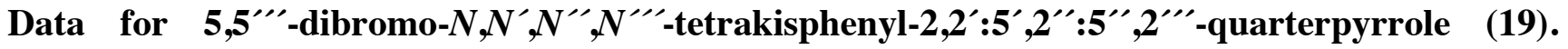
$N, N^{\prime}, N^{\prime \prime}, N^{\prime \prime \prime}-$ Tetrakisphenyl-2,2':5 $, 2^{\prime \prime}: 5^{\prime \prime}, 2^{\prime \prime \prime}$-quarterpyrrol (18) (0.53 g, $\left.0.94 \mathrm{mmol}\right)$ and 2 eq of $N$ bromosuccinimide $(0.33 \mathrm{~g}, 1.88 \mathrm{mmol})$. Yield: $0.62 \mathrm{~g}(0.86 \mathrm{mmol}, 91 \%$ based on 18$)$; colorless solid, soluble in dichloromethane. Anal. calcd for $\mathrm{C}_{40} \mathrm{H}_{28} \mathrm{~N}_{4} \mathrm{Br}_{2}(724.49 \mathrm{~g} / \mathrm{mol})$ [\%]: C, 66.31; H, 3.90; N, 7.73;

found: C, 65.31; H, 3.98; N, 7.50. Mp.: $178{ }^{\circ} \mathrm{C} .{ }^{1} \mathrm{H} \mathrm{NMR}\left[\mathrm{CDCl}_{3}, \mathrm{ppm}\right] \delta: 5.92\left(\mathrm{~d},{ }^{3} J_{\mathrm{H} 4-\mathrm{H} 3 / \mathrm{H} 4{ }^{\prime \prime \prime}-\mathrm{H} 3^{\prime \prime \prime}}=\right.$ 3.61 Hz, $\left.2 \mathrm{H}, \mathrm{H}-4 / 4^{\prime \prime \prime}\right), 6.03-6.06\left(\mathrm{~m}, 8 \mathrm{H}, \mathrm{C}_{6} \mathrm{H}_{5} / \mathrm{C}_{6} \mathrm{H}_{5}{ }^{\prime \prime \prime} / \mathrm{H}-3 / 3^{\prime \prime \prime} / \mathrm{H}-3^{\prime} / 4^{\prime \prime}\right), 6.18\left(\mathrm{~d},{ }^{3} J_{\mathrm{H} 4^{\prime}-\mathrm{H} 3^{\prime} / \mathrm{H} 3^{\prime \prime}-\mathrm{H} 4^{\prime \prime}}=\right.$ 
$\left.3.77 \mathrm{~Hz}, 2 \mathrm{H}, \mathrm{H}-4^{\prime} / 3^{\prime \prime}\right), 6.58\left(\mathrm{~m}, 4 \mathrm{H}, \mathrm{C}_{6} \mathrm{H}_{5}{ }^{\prime} / \mathrm{C}_{6} \mathrm{H}_{5}{ }^{\prime \prime}\right), 6.85$ (m, $\left.4 \mathrm{H}, \mathrm{C}_{6} \mathrm{H}_{5} / \mathrm{C}_{6} \mathrm{H}_{5}{ }^{\prime \prime \prime}\right), 7.00$ (m, $2 \mathrm{H}$, $\left.\mathrm{C}_{6} \mathrm{H}_{5} / \mathrm{C}_{6} \mathrm{H}_{5}{ }^{\prime \prime \prime}\right), 7.12\left(\mathrm{~m}, 4 \mathrm{H}, \mathrm{C}_{6} \mathrm{H}_{5}{ }^{\prime} / \mathrm{C}_{6} \mathrm{H}_{5}{ }^{\prime \prime}\right), 7.21\left(\mathrm{~m}, 2 \mathrm{H}, \mathrm{C}_{6} \mathrm{H}_{5}{ }^{\prime} / \mathrm{C}_{6} \mathrm{H}_{5}{ }^{\prime \prime}\right) .{ }^{13} \mathrm{C}\left\{{ }^{1} \mathrm{H}\right\} \mathrm{NMR}\left[\mathrm{CDCl}_{3}, \mathrm{ppm}\right]$

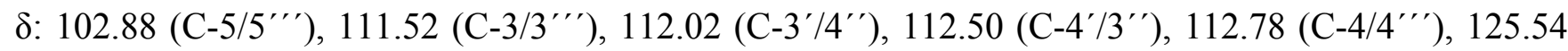
$\left(\mathrm{C}_{i}-\mathrm{C}-2^{\prime} / 5^{\prime \prime}\right), \quad 125.78 \quad\left(\mathrm{C}_{6} \mathrm{H}_{5} / \mathrm{C}_{6} \mathrm{H}_{5}{ }^{\prime \prime \prime}\right), \quad 126.23 \quad\left(\mathrm{C}_{i}-\mathrm{C}-2 / 2^{\prime \prime \prime}\right), \quad 126.64 \quad\left(\mathrm{C}_{6} \mathrm{H}_{5} / \mathrm{C}_{6} \mathrm{H}_{5}{ }^{\prime \prime \prime}\right), \quad 127.32$ $\left(\mathrm{C}_{6} \mathrm{H}_{5^{\prime}} / \mathrm{C}_{6} \mathrm{H}_{5^{\prime \prime}}\right), 127.67\left(\mathrm{C}_{i^{-}} \mathrm{C}-5^{\prime} / 2^{\prime \prime}\right), 127.85\left(\mathrm{C}_{6} \mathrm{H}_{5^{\prime}} / \mathrm{C}_{6} \mathrm{H}_{5^{\prime \prime}}\right), 128.14\left(\mathrm{C}_{6} \mathrm{H}_{5} / \mathrm{C}_{6} \mathrm{H}_{5^{\prime}} / \mathrm{C}_{6} \mathrm{H}_{5^{\prime \prime}} / \mathrm{C}_{6} \mathrm{H}_{5^{\prime \prime}}\right), 137.88$ $\left(\mathrm{C}_{i}-\mathrm{C}_{6} \mathrm{H}_{5} / \mathrm{C}_{6} \mathrm{H}_{5}{ }^{\prime \prime \prime}\right), 138.14\left(\mathrm{C}_{i}-\mathrm{C}_{6} \mathrm{H}_{5}{ }^{\prime} / \mathrm{C}_{6} \mathrm{H}_{5}{ }^{\prime \prime}\right) . \mathrm{IR}$ data $\left[\mathrm{KBr}, \mathrm{cm}^{-1}\right]$ v: $766\left(\mathrm{~s}, \delta_{\text {o.o.p. }}=\mathrm{C}-\mathrm{H}\right), 1497\left(\mathrm{~s}, v_{\mathrm{C}=\mathrm{C}}\right)$, $1596\left(\mathrm{~m}, v_{\mathrm{C}=\mathrm{C}}\right), 3042\left(\mathrm{w}, v_{=\mathrm{C}-\mathrm{H}}\right)$. HR-ESI-MS [m/z]: calcd for $\mathrm{C}_{40} \mathrm{H}_{28} \mathrm{~N}_{4} \mathrm{Br}_{2}:$ 724.0694, found: 724.0659 $[\mathrm{M}]$.

General procedure - Synthesis of diferrocenyl oligopyrroles 8, 15 and 19. Ferrocene and $\mathrm{KO}^{t} \mathrm{Bu}$ (0.125 eq) were dissolved in $20 \mathrm{~mL}$ of tetrahydrofuran and the solution was cooled to $-80{ }^{\circ} \mathrm{C}$. ${ }^{t}$ Butyllithium (2 eq, $1.6 \mathrm{M}$ in $n$-pentane) was added dropwise via a syringe and the solution was stirred for $1 \mathrm{~h}$. Then $\left[\mathrm{ZnCl}_{2} \cdot 2 \mathrm{thf}\right]$ (1 eq) was added in a single portion. The reaction mixture was stirred for additional $30 \mathrm{~min}$ at $0{ }^{\circ} \mathrm{C}$. Afterward, $0.25 \mathrm{~mol} \%$ of $\left[\mathrm{Pd}\left(\mathrm{CH}_{2} \mathrm{C}\left(\mathrm{CH}_{3}\right)_{2} \mathrm{P}\left({ }^{t} \mathrm{C}_{4} \mathrm{H}_{9}\right)_{2}\right)(\mu-\mathrm{Cl})\right]_{2}$ and $1 / 3$ eq of the bromo oligopyrroles $\mathbf{8 , 1 5}$ or $\mathbf{1 9}$ were added in a single portion and the reaction solutions were stirred overnight at $60^{\circ} \mathrm{C}$. The crude product was worked-up by column chromatography (column size: $1.5 \mathrm{x}$ $10 \mathrm{~cm}$, alumina pretreated with triethyl amine). The $1^{\text {st }}$ fraction contained ferrocene, while from the $2^{\text {nd }}$ fraction $9, \mathbf{1 6}$ or $\mathbf{2 0}$ could be isolated. All volatiles were removed under reduced pressure.

Data for 5,5'-diferrocenyl- $\boldsymbol{N}, \boldsymbol{N}^{\prime}$-bisphenyl-2,2'-bipyrrole (9). Ferrrocene (0.35 g, $\left.1.89 \mathrm{mmol}\right)$, 0.125 eq of $\mathrm{KO}^{t} \mathrm{Bu}(27 \mathrm{mg}, 0.24 \mathrm{mmol}), 2$ eq of butyllithium $(2.35 \mathrm{~mL}, 3.78 \mathrm{mmol}), 1.0$ eq of $\left[\mathrm{ZnCl}_{2} \cdot 2\right.$ thf $](527 \mathrm{mg}, 1.89 \mathrm{mmol}), 1 / 3 \mathrm{eq}$ of 5,5'-dibromo- $N, N^{\prime}$-bisphenyl-2,2'-bipyrrol (8) (0.28 g, $0.63 \mathrm{mmol})$ and $0.25 \mathrm{~mol} \%$ of $\left[\mathrm{Pd}\left(\mathrm{CH}_{2} \mathrm{C}\left(\mathrm{CH}_{3}\right)_{2} \mathrm{P}\left({ }^{t} \mathrm{C}_{4} \mathrm{H}_{9}\right)_{2}\right)(\mu-\mathrm{Cl})\right]_{2}(2.14 \mathrm{mg})$. As eluent for column chromatography a $n$-hexane/diethyl ether mixture of ratio 10:1 $(v / v)$ was used. Yield: $0.3 \mathrm{~g}(0.45 \mathrm{mmol}$, $73 \%$ based on 8); pale orange solid, soluble in dichloromethane. Anal. calcd for $\mathrm{C}_{40} \mathrm{H}_{32} \mathrm{~N}_{2} \mathrm{Fe}_{2}(652.38$ 
g/mol) [\%]: C, 73.64; H, 4.94; N, 4.29; found: C, 73.61; H, 5.40; N, 4.10. Mp.: $221{ }^{\circ} \mathrm{C} .{ }^{1} \mathrm{H}$ NMR $\left[\mathrm{CDCl}_{3}, \mathrm{ppm}\right] \delta: 3.84\left(\mathrm{pt}, J_{\mathrm{HH}}=1.90 \mathrm{~Hz}, 4 \mathrm{H}, \mathrm{C}_{5} \mathrm{H}_{4}\right), 3.97\left(\mathrm{~s}, 10 \mathrm{H}, \mathrm{C}_{5} \mathrm{H}_{5}\right), 3.98\left(\mathrm{pt}, J_{\mathrm{HH}}=1.90 \mathrm{~Hz}, 4 \mathrm{H}\right.$, $\left.\mathrm{C}_{5} \mathrm{H}_{4}\right), 6.03\left(\mathrm{~d},{ }^{3} \mathrm{~J}_{\mathrm{H} 3-\mathrm{H} 4}=3.67 \mathrm{~Hz}, 2 \mathrm{H}, \mathrm{H}-3\right), 6.30\left(\mathrm{~d},{ }^{3} J_{\mathrm{H} 4-\mathrm{H} 3}=3.67 \mathrm{~Hz}, 2 \mathrm{H}, \mathrm{H}-4\right), 6.85\left(\mathrm{~m}, 4 \mathrm{H}, \mathrm{C}_{6} \mathrm{H}_{5} / o-\right.$ $\mathrm{H}), 7.22-7.25\left(\mathrm{~m}, 6 \mathrm{H}, \mathrm{C}_{6} \mathrm{H}_{5}\right) .{ }^{13} \mathrm{C}\left\{{ }^{1} \mathrm{H}\right\} \mathrm{NMR}\left[\mathrm{CDCl}_{3}, \mathrm{ppm}\right] \delta: 67.51\left(\mathrm{C}_{5} \mathrm{H}_{4}\right), 67.56\left(\mathrm{C}_{5} \mathrm{H}_{4}\right), 69.60$ $\left(\mathrm{C}_{5} \mathrm{H}_{5}\right), 79.26\left(\mathrm{C}_{i}-\mathrm{C}_{5} \mathrm{H}_{4}\right), 108.09(\mathrm{C}-4), 112.47(\mathrm{C}-3), 126.65(\mathrm{C}-5), 127.41\left(\mathrm{C}_{6} \mathrm{H}_{5}\right), 128.27\left(\mathrm{C}_{6} \mathrm{H}_{5}\right)$, $129.08\left(\mathrm{C}_{6} \mathrm{H}_{5}\right), 131.85\left(\mathrm{C}_{i^{-}} \mathrm{C}-2\right), 139.41\left(\mathrm{C}_{i}-\mathrm{C}_{6} \mathrm{H}_{5}\right) . \mathrm{IR}$ data $\left[\mathrm{KBr}, \mathrm{cm}^{-1}\right]$ v: 775 (s, $\left.\delta_{\text {o.o.p. }=\mathrm{c}-\mathrm{H}}\right), 1105(\mathrm{~m}$, $\left.v_{\mathrm{C}-\mathrm{N}}\right), 1500\left(\mathrm{~s}, v_{\mathrm{C}=\mathrm{C}}\right), 1590\left(\mathrm{~m}, v_{\mathrm{C}=\mathrm{C}}\right), 3080\left(\mathrm{w}, v_{=\mathrm{C}-\mathrm{H}}\right)$. HR-ESI-MS [m/z]: calcd for $\mathrm{C}_{40} \mathrm{H}_{32} \mathrm{~N}_{2} \mathrm{Fe}_{2}$ : 652.1260, found: $652.1263[\mathrm{M}]$.

Data for $5,5^{\prime \prime}$-diferrocenyl- $N, N^{\prime}, N^{\prime \prime}$-trisphenyl-2,2':5',2"-terpyrrole (16). Ferrrocene (383 mg, $2.06 \mathrm{mmol}), 0.125 \mathrm{eq}$ of $\mathrm{KO}^{t} \mathrm{Bu}(29 \mathrm{mg}, 0.26 \mathrm{mmol}), 2$ eq of ${ }^{t}$ butyllithium $(2.57 \mathrm{~mL}, 4.12 \mathrm{mmol}), 1.0 \mathrm{eq}$

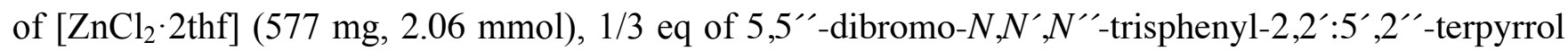
(15) $(0.40 \mathrm{~g}, 0.69 \mathrm{mmol})$ and $0.25 \mathrm{~mol} \%$ of $\left[\mathrm{Pd}\left(\mathrm{CH}_{2} \mathrm{C}\left(\mathrm{CH}_{3}\right)_{2} \mathrm{P}\left({ }^{t} \mathrm{C}_{4} \mathrm{H}_{9}\right)_{2}\right)(\mu-\mathrm{Cl})\right]_{2}(2.35 \mathrm{mg})$. As eluent for column chromatography a $n$-hexane/diethyl ether mixture of ratio $2: 1(v / v)$ was used. Yield: $0.3 \mathrm{~g}(0.38$ mmol, $55 \%$ based on 15); orange solid, soluble in dichloromethane. Anal. calcd for $\mathrm{C}_{50} \mathrm{H}_{39} \mathrm{~N}_{3} \mathrm{Fe}_{2} \cdot 0.85 \mathrm{Et}_{2} \mathrm{O}(856.55 \mathrm{~g} / \mathrm{mol})[\%]: \mathrm{C}, 74.87 ; \mathrm{H}, 5.59 ; \mathrm{N}, 4.90$; found: $\mathrm{C}, 74.56 ; \mathrm{H}, 5.30 ; \mathrm{N}, 4.90$. Mp.: $185{ }^{\circ} \mathrm{C}$ (decomp.). ${ }^{1} \mathrm{H}$ NMR $\left[\left(\mathrm{CD}_{3}\right)_{2} \mathrm{SO}, \mathrm{ppm}\right] \delta: 3.78$ (pt, $\left.J_{\mathrm{HH}}=1.88 \mathrm{~Hz}, 4 \mathrm{H}, \mathrm{C}_{5} \mathrm{H}_{4}\right), 3.92(\mathrm{~s}, 10$ $\left.\mathrm{H}, \mathrm{C}_{5} \mathrm{H}_{5}\right), 4.01\left(\mathrm{pt}, J_{\mathrm{HH}}=1.88 \mathrm{~Hz}, 4 \mathrm{H}, \mathrm{C}_{5} \mathrm{H}_{4}\right), 5.70\left(\mathrm{~d},{ }^{3} J_{\mathrm{HH}}=3.65 \mathrm{~Hz}, 2 \mathrm{H}, \mathrm{H}-3 / 3^{\prime \prime}\right), 5.72(\mathrm{~s}, 2 \mathrm{H}$, H-3'/4'), $6.25\left(\mathrm{~d},{ }^{3} J_{\mathrm{HH}}=3.65 \mathrm{~Hz}, 2 \mathrm{H}, \mathrm{H}-4 / 4^{\prime \prime}\right), 6.70\left(\mathrm{~m}, 2 \mathrm{H}, \mathrm{C}_{6} \mathrm{H}_{5}{ }^{\prime} / o-\mathrm{H}\right), 6.82(\mathrm{~m}, 4 \mathrm{H}$, $\left.\mathrm{C}_{6} \mathrm{H}_{5} / \mathrm{C}_{6} \mathrm{H}_{5}{ }^{\prime \prime} / o-\mathrm{H}\right), 7.21$ (m, $\left.3 \mathrm{H}, \mathrm{C}_{6} \mathrm{H}_{5}{ }^{\prime}\right), 7.32\left(\mathrm{~m}, 4 \mathrm{H}, \mathrm{C}_{6} \mathrm{H}_{5} / \mathrm{C}_{6} \mathrm{H}_{5}{ }^{\prime \prime} / m-\mathrm{H}\right), 7.39$ (m, $2 \mathrm{H}, \mathrm{C}_{6} \mathrm{H}_{5} / \mathrm{C}_{6} \mathrm{H}_{5}{ }^{\prime \prime} / p-$ H). ${ }^{13} \mathrm{C}\left\{{ }^{1} \mathrm{H}\right\}$ NMR $\left[\left(\mathrm{CD}_{3}\right)_{2} \mathrm{SO}, \mathrm{ppm}\right] \delta: 66.28\left(\mathrm{C}_{5} \mathrm{H}_{4}\right), 67.29\left(\mathrm{C}_{5} \mathrm{H}_{4}\right), 69.20\left(\mathrm{C}_{5} \mathrm{H}_{5}\right), 78.42\left(\mathrm{C}_{i}-\mathrm{C}_{5} \mathrm{H}_{4}\right)$, $107.67\left(\mathrm{C}_{4} \mathrm{~N}\right), 111.34\left(\mathrm{C}_{4} \mathrm{~N}\right), 111.64\left(\mathrm{C}_{4} \mathrm{~N}\right), 125.48\left(\mathrm{C}_{i}{ }^{-} \mathrm{C}-5 / 5^{\prime \prime}\right), 126.12\left(\mathrm{C}_{i}-\mathrm{C}-2 / 2^{\prime \prime}\right), 126.59\left(\mathrm{C}_{6} \mathrm{H}_{5}{ }^{\prime}\right)$, $127.70\left(\mathrm{C}_{6} \mathrm{H}_{5} / \mathrm{C}_{6} \mathrm{H}_{5}{ }^{\prime \prime}\right), 127.86\left(\mathrm{C}_{6} \mathrm{H}_{5}{ }^{\prime}\right), 127.98\left(\mathrm{C}_{6} \mathrm{H}_{5}{ }^{\prime}\right), 128.34\left(\mathrm{C}_{6} \mathrm{H}_{5} / \mathrm{C}_{6} \mathrm{H}_{5}{ }^{\prime \prime}\right), 128.83\left(\mathrm{C}_{6} \mathrm{H}_{5} / \mathrm{C}_{6} \mathrm{H}_{5}{ }^{\prime \prime}\right)$, $131.25\left(\mathrm{C}_{i}{ }^{-} \mathrm{C}-2^{\prime} / 5^{\prime}\right), 138.43\left(\mathrm{C}_{i}{ }^{-} \mathrm{C}_{6} \mathrm{H}_{5}{ }^{\prime}\right), 138.59\left(\mathrm{C}_{i}-\mathrm{C}_{6} \mathrm{H}_{5} / \mathrm{C}_{i}{ }^{-} \mathrm{C}_{6} \mathrm{H}_{5}{ }^{\prime \prime}\right)$. IR data $\left[\mathrm{KBr}, \mathrm{cm}^{-1}\right]$ v: $768\left(\mathrm{~s}, \delta_{\text {o.o.p. }}\right.$ 
$=\mathrm{C}-\mathrm{H}), 1497\left(\mathrm{~s}, v_{\mathrm{C}=\mathrm{C}}\right), 1596\left(\mathrm{~m}, v_{\mathrm{C}=\mathrm{C}}\right), 3055,3098\left(\mathrm{w}, v_{=\mathrm{C}-\mathrm{H}}\right)$. HR-ESI-MS [m/z]: calcd for $\mathrm{C}_{50} \mathrm{H}_{39} \mathrm{~N}_{3} \mathrm{Fe}_{2}$ :

794.1918, found: $794.1815[\mathrm{M}]^{+}$.

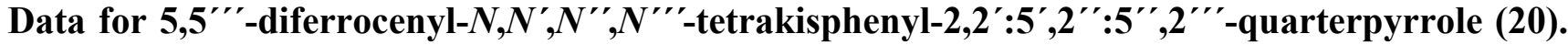

Ferrrocene (466 mg, $2.5 \mathrm{mmol}), 0.125$ eq of $\mathrm{KO}^{t} \mathrm{Bu}(35 \mathrm{mg}, 0.31 \mathrm{mmol}), 2$ eq of ${ }^{t}$ butyllithium $(3.13 \mathrm{~mL}$, $5.0 \mathrm{mmol}), 1.0 \mathrm{eq}$ of $\left[\mathrm{ZnCl}_{2} \cdot 2 \mathrm{thf}\right](0.70 \mathrm{~g}, 2.5 \mathrm{mmol}), 1 / 3 \mathrm{eq}$ of $5,5^{\prime \prime \prime}$-dibromo- $N, N^{\prime}, N^{\prime \prime}, N^{\prime \prime \prime}-$

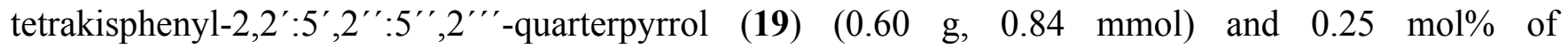
$\left[\mathrm{Pd}\left(\mathrm{CH}_{2} \mathrm{C}\left(\mathrm{CH}_{3}\right)_{2} \mathrm{P}\left({ }^{t} \mathrm{C}_{4} \mathrm{H}_{9}\right)_{2}\right)(\mu-\mathrm{Cl})\right]_{2} \quad(4.30 \mathrm{mg})$. For column chromatography a $n$-hexane/dichloromethane mixture of ratio 5:1 $(v / v)$ was used as eluent. Yield: $0.65 \mathrm{~g}(0.69 \mathrm{mmol}, 83 \%$ based on 19); orange solid, soluble in dichloromethane. Anal. calcd for $\mathrm{C}_{40} \mathrm{H}_{46} \mathrm{~N}_{4} \mathrm{Fe}_{2}(934.24 \mathrm{~g} / \mathrm{mol})[\%]$ : C, 77.10; $\mathrm{H}$, 4.96; N, 5.99; found: C, 77.03; H, 5.36; N, 5.83. Mp.: $227^{\circ} \mathrm{C}$ (decomp.). ${ }^{1} \mathrm{H}$ NMR [CDCl 3 , ppm] $\delta: 3.80$ (pt, $\left.J_{\mathrm{HH}}=1.89 \mathrm{~Hz}, 4 \mathrm{H}, \mathrm{C}_{5} \mathrm{H}_{4}\right), 3.95\left(\mathrm{~s}, 10 \mathrm{H}, \mathrm{C}_{5} \mathrm{H}_{5}\right), 3.97\left(\mathrm{pt}, J_{\mathrm{HH}}=1.90 \mathrm{~Hz}, 4 \mathrm{H}, \mathrm{C}_{5} \mathrm{H}_{4}\right), 5.95\left(\mathrm{~d},{ }^{3} J_{\mathrm{HH}}\right.$ $\left.=3.58 \mathrm{~Hz}, 2 \mathrm{H}, \mathrm{H}-4 / 4^{\prime \prime \prime}\right), 6.03\left(\mathrm{~d},{ }^{3} J_{\mathrm{HH}}=3.67 \mathrm{~Hz}, 2 \mathrm{H}, \mathrm{H}-3^{\prime} / 4^{\prime \prime}\right), 6.06\left(\mathrm{~d},{ }^{3} J_{\mathrm{HH}}=3.56 \mathrm{~Hz}, 2 \mathrm{H}\right.$, $\left.\mathrm{H}-3 / 3^{\prime \prime \prime}\right), 6.14\left(\mathrm{~m}, 4 \mathrm{H}, \mathrm{C}_{6} \mathrm{H}_{5} / \mathrm{C}_{6} \mathrm{H}_{5}{ }^{\prime \prime \prime}\right), 6.30\left(\mathrm{~d},{ }^{3} \mathrm{~J}_{\mathrm{HH}}=3.67 \mathrm{~Hz}, 2 \mathrm{H}, \mathrm{H}-4^{\prime} / 3^{\prime \prime}\right), 6.55(\mathrm{~m}, 4 \mathrm{H}$, $\left.\mathrm{C}_{6} \mathrm{H}_{5}{ }^{\prime} / \mathrm{C}_{6} \mathrm{H}_{5}{ }^{\prime \prime}\right), 6.86\left(\mathrm{~m}, 4 \mathrm{H}, \mathrm{C}_{6} \mathrm{H}_{5} / \mathrm{C}_{6} \mathrm{H}_{5}{ }^{\prime \prime \prime}\right), 6.97$ (m, $\left.2 \mathrm{H}, \mathrm{C}_{6} \mathrm{H}_{5} / \mathrm{C}_{6} \mathrm{H}_{5}{ }^{\prime \prime \prime}\right), 7.10$ (m, $\left.4 \mathrm{H}, \mathrm{C}_{6} \mathrm{H}_{5}{ }^{\prime} / \mathrm{C}_{6} \mathrm{H}_{5}{ }^{\prime \prime}\right)$, $7.21\left(\mathrm{~m}, 2 \mathrm{H}, \mathrm{C}_{6} \mathrm{H}_{5}{ }^{\prime} / \mathrm{C}_{6} \mathrm{H}_{5}{ }^{\prime \prime}\right) .{ }^{13} \mathrm{C}\left\{{ }^{1} \mathrm{H}\right\} \mathrm{NMR}\left[\mathrm{CDCl}_{3}, \mathrm{ppm}\right] \delta: 67.47\left(\mathrm{C}_{5} \mathrm{H}_{4}\right), 67.53\left(\mathrm{C}_{5} \mathrm{H}_{4}\right), 69.60\left(\mathrm{C}_{5} \mathrm{H}_{5}\right)$, $79.09\left(\mathrm{C}_{i}-\mathrm{C}_{5} \mathrm{H}_{4}\right), 108.09\left(\mathrm{C}_{4} \mathrm{~N}\right), 111.77\left(\mathrm{C}_{4} \mathrm{~N}\right), 112.32\left(\mathrm{C}_{4} \mathrm{~N}\right), 112.41\left(\mathrm{C}_{4} \mathrm{~N}\right), 125.47\left(\mathrm{C}_{6} \mathrm{H}_{5} / \mathrm{C}_{6} \mathrm{H}_{5}{ }^{\prime \prime \prime}\right)$, $126.07\left(\mathrm{C}_{i}-\mathrm{C}-2 / 2^{\prime \prime}\right), \quad 126.10\left(\mathrm{C}_{i}-\mathrm{C}-2^{\prime} / 5^{\prime \prime}\right), \quad 126.53\left(\mathrm{C}_{i}-\mathrm{C}-5 / 5^{\prime \prime \prime}\right), \quad 126.77 \quad\left(\mathrm{C}_{6} \mathrm{H}_{5} / \mathrm{C}_{6} \mathrm{H}_{5}{ }^{\prime \prime \prime}\right), 127.04$ $\left(\mathrm{C}_{6} \mathrm{H}_{5}{ }^{\prime} / \mathrm{C}_{6} \mathrm{H}_{5}{ }^{\prime \prime}\right), 127.65\left(\mathrm{C}_{6} \mathrm{H}_{5}{ }^{\prime} / \mathrm{C}_{6} \mathrm{H}_{5}{ }^{\prime \prime}\right), 127.97\left(\mathrm{C}_{6} \mathrm{H}_{5} / \mathrm{C}_{6} \mathrm{H}_{5}{ }^{\prime \prime \prime}\right), 128.68\left(\mathrm{C}_{6} \mathrm{H}_{5}{ }^{\prime} / \mathrm{C}_{6} \mathrm{H}_{5}{ }^{\prime \prime}\right), 131.09\left(\mathrm{C}_{i}-\mathrm{C}-\right.$ 5'/2"'), $138.55\left(\mathrm{C}_{i}-\mathrm{C}_{6} \mathrm{H}_{5} / \mathrm{C}_{i}-\mathrm{C}_{6} \mathrm{H}_{5}{ }^{\prime \prime \prime}\right), 138.98\left(\mathrm{C}_{i}-\mathrm{C}_{6} \mathrm{H}_{5}{ }^{\prime} / \mathrm{C}_{i}-\mathrm{C}_{6} \mathrm{H}_{5}{ }^{\prime \prime}\right)$. IR data $\left[\mathrm{KBr}, \mathrm{cm}^{-1}\right]$ v: 769 (s, $\delta_{\text {o.o.p. }}$ $=\mathrm{C}-\mathrm{H}), 1498\left(\mathrm{~s}, v_{\mathrm{C}=\mathrm{C}}\right), 1596\left(\mathrm{~m}, v_{\mathrm{C}=\mathrm{C}}\right), 3055,3091\left(\mathrm{w}, \mathrm{v}_{=\mathrm{C}-\mathrm{H}}\right)$. HR-ESI-MS [m/z]: calcd for $\mathrm{C}_{60} \mathrm{H}_{46} \mathrm{~N}_{4} \mathrm{Fe}_{2}$ : 934.2419, found: 934.2410 [M].

Single crystal X-ray diffraction analysis. Data were collected on an Oxford Gemini S diffractometer using graphite-monochromatized Mo K $\alpha$ radiation $(\lambda=0.71073 \AA$ ) (compound 9) or $\mathrm{Cu} \mathrm{K} \alpha$ radiation $(1.54184 \AA)(\mathbf{1 6}, \mathbf{2 0})$. The molecular structures were solved by direct methods using SHELXS-97 ${ }^{52}$ and refined by full-matrix least-squares procedures on $\mathrm{F}^{2}$ using SHELXL-97. ${ }^{53}$ All non-hydrogen atoms 
were refined anisotropically and a riding model was employed in the treatment of the hydrogen atom positions.

Crystal data for 9. Single crystals of 9 were obtained by diffusion of methanol into a dichloromethane solution containing 9 at $25^{\circ} \mathrm{C} . \mathrm{C}_{40} \mathrm{H}_{32} \mathrm{Fe}_{2} \mathrm{~N}_{2}, M_{\mathrm{r}}=652.38 \mathrm{~g} \cdot \mathrm{mol}^{-1}$, crystal dimensions $0.15 \times 0.12 \times 0.08 \mathrm{~mm}$, triclinic, $P-1, \lambda=0.71073 \AA, a=12.8550(5) \AA, b=16.1262(4) \AA, c=$ 16.9337(6) $\AA, \alpha=112.931(3)^{\circ}, \beta=105.841(3)^{\circ}, \gamma=97.547(3)^{\circ}, V=2996.19(17) \AA^{3}, Z=4, \rho_{\text {calcd }}=$ $1.446 \mathrm{~g} \cdot \mathrm{cm}^{-3}, \mu=1.001 \mathrm{~mm}^{-1}, T=110 \mathrm{~K}, \Theta$ range $=2.90-26.00^{\circ}$, reflections collected 27603 , independent 11692, $R_{1}=0.0387, w R_{2}=0.0772[I \geq 2 \sigma(I)]$.

Crystal data for 16.0. MeOH. Single crystals of 16.0.5 MeOH were obtained by diffusion of methanol into a dichloromethane solution containing 16 at $25{ }^{\circ} \mathrm{C} . \mathrm{C}_{50.5} \mathrm{H}_{41} \mathrm{Fe}_{2} \mathrm{~N}_{3} \mathrm{O}_{0.5}, M_{\mathrm{r}}=809.56$ $\mathrm{g} \cdot \mathrm{mol}^{-1}$, crystal dimensions $0.40 \times 0.10 \times 0.01 \mathrm{~mm}$, monoclinic, $P 2_{1} / c, \lambda=1.54184 \AA, a=16.2608(7) \AA$, $b=23.0890(11) \AA, c=10.5432(4) \AA, \beta=98.853(4)^{\circ}, V=3910.9(3) \AA^{3}, Z=4, \rho_{\text {calcd }}=1.375 \mathrm{~g} \cdot \mathrm{cm}^{-3}, \mu$ $=6.263 \mathrm{~mm}^{-1}, T=115 \mathrm{~K}, \Theta$ range $=3.35-63.99^{\circ}$, reflections collected 12791 , independent $6392, R_{1}=$ $0.0598, w R_{2}=0.1297[I \geq 2 \sigma(I)]$.

Crystal data for 20. Single crystals of 20 were obtained by diffusion of toluene into a dichloromethane solution containing 20 at $25^{\circ} \mathrm{C} . \mathrm{C}_{60} \mathrm{H}_{46} \mathrm{Fe}_{2} \mathrm{~N}_{4}, M_{\mathrm{r}}=934.71 \mathrm{~g} \cdot \mathrm{mol}^{-1}$, crystal dimensions $0.36 \times 0.18 \times 0.12 \mathrm{~mm}$, triclinic, $P-1, \lambda=1.54184 \AA, a=7.2632(3) \AA, b=15.1417(6) \AA, c=20.1823(8)$ $\AA, \alpha=76.704(3)^{\circ}, \beta=87.070(3)^{\circ}, \gamma=79.227(3)^{\circ}, V=2188.19(15) \AA^{3}, Z=2, \rho_{\text {calcd }}=1.419 \mathrm{~g} \cdot \mathrm{cm}^{-3}, \mu$

$=5.677 \mathrm{~mm}^{-1}, T=115 \mathrm{~K}, \Theta$ range $=3.05-62.93^{\circ}$, reflections collected 12059 , independent $6903, R_{1}=$ $0.0455, w R_{2}=0.1122[I \geq 2 \sigma(I)]$.

\section{AUTHOR INFORMATION}

*Corresponding author. E-mail: heinrich.lang@chemie.tu-chemnitz.de; phone: +49 (0)371-531-21210; fax.: +49 (0)371-531-21219. 


\section{ACKNOWLEDGEMENT}

We are grateful to the Deutsche Forschungsgemeinschaft and the Fonds der Chemischen Industrie for generous financial support.

\section{REFERENCES}

(1) Lapinte, C.; Paul, F. Coord. Chem. Rev. 1998, 180, 431-509.

(2) Low, P. J. Dalton Trans. 2005, 2821-2824.

(3) Tour, J. M. Acc. Chem. Res. 2000, 33, 791-804.

(4) Ying, J.-W.; Liu, I. P.-C.; Xi, B.; Song, Y.; Campana, C.; Zuo, J.-L.; Ren, T. Angew. Chem. Int. Ed. 2010, 49, 954-957.

(5) Ward, M. D. Chem. Soc. Rev. 1995, 24, 121-134.

(6) Samoc, M.; Gauthier, N.; Cifuentes, M. P.; Paul, F.; Lapinte, C.; Humphrey, M. G. Angew. Chem. Int. Ed. 2006, 45, 7376-7379.

(7) Structures, S.; Couplings, E.; Lohan, M.; Roisnel, T.; Ecorchard, P.; Lang, H.; Lapinte, C. Organometallics 2010, 4804-4817.

(8) Sato, M.; Kubota, Y.; Tanemura, A.; Maruyama, G.; Fujihara, T.; Nakayama, J.; Takayanagi, T.; Takahashi, K.; Unoura, K. Eur. J. Inorg. Chem. 2006, 2006, 4577-4588.

(9) Bruce, M. I.; Low, P. J.; Costuas, K.; Best, S. P.; Heath, G. A. J. Am. Chem. Soc. 2000, 19491962.

(10) Fox, M. A.; Le Guennic, B.; Roberts, R. L.; Brue, D. A.; Yufit, D. S.; Howard, J. A. K.; Manca, G.; Halet, J.-F.; Hartl, F.; Low, P. J. J. Am. Chem. Soc 2011, 133, 18433-18446.

(11) Levanda, C.; Bechgaard, K.; Cowan, D. O. J. Org. Chem. 1976, 41, 2700-2704.

(12) Connelly, N. G.; Geiger, W. E. Chem. Rev. 1996, 96, 877-910. 
(13) Ribou, A.-C.; Launay, J.-P.; Sachtleben, M. L.; Li, H.; Spangler, C. W. Inorg. Chem. 1996, 35 , 3735-3740.

(14) Sundararaman, A.; Venkatasubbaiah, K.; Victor, M.; Zakharov, L. N.; Rheingold, A. L.; Jäkle, F. J. Am. Chem. Soc. 2006, 128, 16554-16565.

(15) Iyoda, M.; Kondo, T.; Okabe, T.; Matsuyama, H.; Sasaki, S.; Kuwatani, Y. Chem. Lett. 1997, 35, 35-36.

(16) Hildebrandt, A.; Pfaff, U.; Lang, H. Rev. Inorg. Chem. 2011, 31, 111-141.

(17) Pfaff, U.; Hildebrandt, A.; Schaarschmidt, D.; Hahn, T.; Liebing, S.; Kortus, J.; Lang, H. Organometallics 2012, 31, 6761-6771.

(18) Skibar, W.; Kopacka, H.; Wurst, K.; Salzmann, C.; Ongania, K.-H.; Fabrizi de Biani, F.; Zanello, P.; Bildstein, B. Organometallics 2004, 23, 1024-1041.

(19) Hradsky, A.; Bildstein, B.; Schuler, N.; Schottenberger, H.; Jaitner, P.; Ongania, K.-H.; Wurst, K.; Launay, J.-P. Organometallics 1997, 16, 392-402.

(20) Sato, M.-A.; Fukui, K. Synth. Met. 2007, 157, 619-626.

(21) Sato, M.; Fukui, K.; Sakamoto, M.; Kashiwagi, S.; Hiroi, M. Thin Solid Films 2001, 393, 210_ 216.

(22) Hildebrandt, A.; Schaarschmidt, D.; Claus, R.; Lang, H. Inorg. Chem. 2011, 10623-10632.

(23) Hildebrandt, A.; Schaarschmidt, D.; Lang, H. Organometallics 2011, 30, 556-563.

(24) Low, P. J.; Brown, N. J. J. Clust. Sci. 2010, 21, 235-278.

(25) Gilow, H. M.; Burton, D. E. J. Org. Chem. 1981, 46, 2221-2225.

(26) Clark, H. C.; Goel, A. B. Inorg. Chim. Acta 1978, 31, 441-442.

(27) Sanders, R.; Mueller-Westerhoff, U. T. J. Organomet. Chem. 1996, 512, 219-224.

(28) Smith, M. B.; March, J. March's Advanced Organic Chemistry: Reactions, Mechanisms, and Structure; 5th ed.; Wiley-VCH: New York, 2001; pp. 20-36.

(29) Bird, C. W.; Cheeseman, G. W. H. Comprehensive Heterocycles; Katritzky, A. R.; Rees, C. W., Eds.; Pergamon Press: Oxford, 1984; pp. 1-10.

(30) Lotz, S.; Crause, C.; Olivier, A. J.; Liles, D. C.; Görls, H.; Landman, M.; Bezuidenhout, D. I. Dalton Trans. 2009, 697-710.

(31) Ogura, K.; Matsumoto, S.; Kobayashi, T. Heterocycles 2005, 66, 319.

(32) Gericke, H. J.; Barnard, N. I.; Erasmus, E.; Swarts, J. C.; Cook, M. J.; Aquino, M. a. S. Inorg. Chim. Acta 2010, 363, 2222-2232. 
(33) Gritzner, G.; Kuta, J. Pure Appl. Chem. 1984, 56, 461-466.

(34) Bard, A. J.; Faulkner, L. R. Electrochemical Methods: Fundamentals and Applications; 2nd ed.; WILEY-VCH, 2000.

(35) Richardson, D. E.; Taube, H. Inorg. Chem. 1981, 1278-1285.

(36) Speck, M. Ferrocenyl-substituierte Oligothiophone - Synthese und Elektrochemisches Verhalten. Diploma Thesis.; TU Chemnitz, 2010.

(37) Vollhardt, K. P. C.; Schore, N. E. Organische Chemie; 3rd ed.; WILEY-VCH, 2000.

(38) Carey, F. A.; Sundberg, R. J. Advanced Organic Chemistry, Part A: Structur and Mechanisms; 5th ed.; Springer, 2007.

(39) Andrieux, C. P.; Hapiot, P.; Audebert, P.; Guyard, L.; An, M. N. D. Chem. Mater. 1997, 4756, $723-729$.

(40) Geiger, W. E.; Barrière, F. Acc. Chem.Res. 2010, 43, 1030-1039.

(41) Speck, J. M.; Claus, R.; Hildebrandt, A.; Rüffer, T.; Erasmus, E.; van As, L.; Swarts, J. C.; Lang, H. Organometallics 2012, 31, 6373-6380.

(42) Krejčik, M.; Daněk, M.; Hartl, F. J. Electroanal. Chem. 1991, 317, 179-187.

(43) Hush, N. S. Prog. Inorg. Chem. 1967, 8, 391-444.

(44) Hush, N. S. Electrochim. Acta 1968, 13, 1005-1023.

(45) Snyder, L. R. Gradient elution. In HPLC: Advances and Perspectives; Horvath, C., Ed.; Academic Press: New York, 1980; Vol. 1, pp. 208-316.

(46) Zhu, Y.; Wolf, M. O. J. Am. Chem. Soc. 2000, 122, 10121-10125.

(47) Gray, H. B.; Sohn, Y. S.; Hendrickson, N. J. Am. Chem. Soc. 1971, 93, 3603-3612.

(48) Dong, T.-Y.; Lin, M.; Chiang, M. Y.-N.; Wu, J.-Y. Organometallics 2004, 23, 3921-3930.

(49) van Haare, J. A. E. H.; Groenendaal, L.; Peerlings, H. W. I.; Havinga, E. E.; Vekemans, J. A. J. M.; Janssen, R. A. J.; Meijer, E. W. Chem. Mater. 1995, 7, 1984-1989.

(50) LeSuer, R. J.; Buttolph, C.; Geiger, W. E. Anal. Chem. 2004, 76, 6395-401.

(51) Nafady, A.; Geiger, W. E. Organometallics 2008, 5624-5631.

(52) Sheldrick, G. M. Acta Crystallogr., Sect. A 1990, 46, 467-473.

(53) Sheldrick, G. M. Program for Crystal Structure Refinement; Universität Göttingen: Göttingen, Germany, 1997. 


\section{Molecular Wires using (Oligo)pyrroles as Connecting}

\section{Units - An Electron Transfer Study}

Ulrike Pfaff, Alexander Hildebrandt, Dieter Schaarschmidt, Tobias Rüffer, Paul J. Low and Heinrich

$$
\text { Lang }
$$

A series of diferrocenyl (oligo)pyrroles have been prepared using the Negishi $C, C$ cross-coupling protocol. In the electrochemical measurements a separate oxidation of the ferrocenyls (one to three pyrrole units) and additional oxidation processes for the pyrrole units could be observed. The NIR measurements confirm electronic communication between the ferrocenyl termini in the corresponding mixed-valent systems of the (oligo)pyrroles up to three pyrrole units. 


\section{Molecular Wires using (Oligo)pyrroles as Connecting}

\section{Units - An Electron Transfer Study}

Ulrike Pfaff, Alexander Hildebrandt, Dieter Schaarschmidt, Tobias Rüffer, Paul J. Low and Heinrich

\section{Lang}

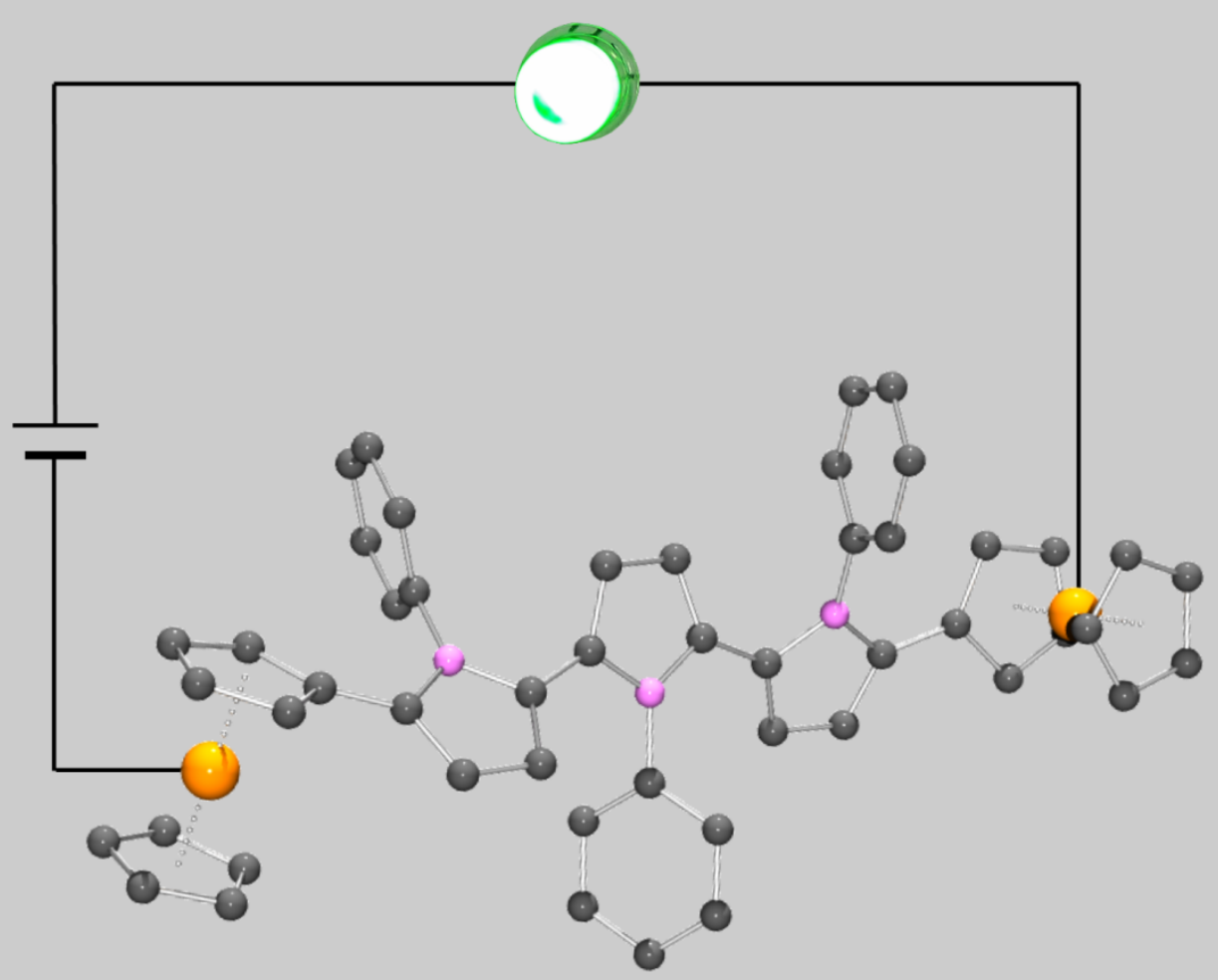

